\title{
The Role of Long-Term Credit Banks \\ Within the Main Bank System
}

\author{
Frank Packer
}

Working Paper No. 77

Frank Packer

Federal Reserve Bank of New York

June 1993

Thanks are due to Toshihiro Horiuchi, Clark Reynolds, Tsutomu Shibata, Marilou Uy, and Hugh Patrick, as well as the participants in the project for their helpful comments on the earlier versions of the paper.

This paper is the final draft for the joint project on the Japanese Main Bank System and its Relevance for Developing Market and Transforming Socialist Economies, undertaken under the auspices of the World bank EDI Program for the Study of Japan's Development Management Experience, the Center on Japanese Economy and Business at Columbia University, and the Economy of Japan Program at the Center for Economic Policy Research, Stanford University. This paper represents the views of the author and not those of the sponsoring institutions.

Working Paper Series

Center on Japanese Economy and Business

Graduate School of Business

Columbia University

October 1993 
List of Tables and Charts

Table 1 Important Distinctions of the Long-Term Credit Bank Law

Table 2 Advantages of Financial Debentures

Table 3

The Share of Outstanding Loans for Plant and Equipment

Table 4 The Industry Breakdown of Cooperative Financing Among the LongInvestment in Selected Industries by Bank Category term Credit Banks and JDB (1967)

Table 5 Main Bank Indicators: The Long-Term Credit Banks compared with Other Banks

Table 6 Comparison of IBJ Clients and Paired Sample (1989/90)

Exhibit 1 The Purchasers of Coupon Debentures by Type

Exhibit 2 Outstanding Financial Debentures by Type

Exhibit 3 The Distribution Channels for Discount Bonds

Exhibit 4 Financial Debentures and the Japanese Bond Market

Exhibit 5 The Distribution of Loans from Major Bank Groups

Exhibit 6 The Position of Second Largest Lender

Exhibit 7 The Collateral of IBJ Loans Compared to that of All Banks

Exhibit 8 The Percent of Loans Going to Plant and Equipment Investment

Exhibit 9 The Percent of Loans which are Long-Term (Over 1 Year)

Exhibit 10 The IBJ Group 
THE ROLE OF LONG-TERM CREDIT BANKS WITHIN THE MAIN BANK SYSTEM

Table of Contents

1. Introduction

II. The Origins and Distinctive Features of the Long-Term Credit Banks

2.1 Origins and Rebirth

2.2 The Long-term Credit Bank Law (1952)

2.2.1 Provisions Constraining the Scope of Business

2.2.2 The Right to Issue Financial Debentures

2.3 The Evolution of the Primary Market for Financial Debentures

2.3.1 The Era of Trust Fund Bureau Purchases

2.3.2 The Purchases of City Banks and Other Banking Institutions

2.3.3 Discount Bonds and the Increasing Importance of Individual Investors

III. Cooperative Financing by the Long-Term Credit Banks

3.1 Cooperative Financing with the Japan Development Bank

3.2 Cooperative Financing with the Group Banks

3.3 Cooperative Financing with Smaller Financial Institutions

IV. The Long-term Credit Bank as a Main Bank

4.1 Bank Loans

4.2 The Supply of Management Information and Resources

4.3 Shareholding

4.4 Payment Settlement Accounts and Bond-Issue Related Services

4.5 The Importance of Ties with Vertical Groups

4.6 Aspects of the IBJ Record for Borrowing Firms in Financial Distress

4.6.1 Active Managerial Intervention

4.6.2 The Search for Merger or Joint Venture Partners

4.6.3 The Securities Industry Crisis

4.6.4 The Case of Japan Line

V. Conclusion

VI. References 


\title{
THE ROLE OF LONG-TERM CREDIT BANKS \\ WITHIN THE MAIN BANK SYSTEM
}

\author{
Frank Packer
}

June 1993

\section{Introduction}

The role of banks in financing Japan's post-war growth has been well-documented. At the same time, there has been increasing recognition that special relationships between certain banks and their customers - "the main bank system" - may have lowered various costs associated with bank debt in Japan, and be partially responsible for the extraordinary reliance on bank debt for most of the post-war period.

One problem with the provision of long-term investment financing by commercial banks is that it can put at risk the uninterrupted provision of liquidity services to the population at large. Though economic models often abstract away from this problem with the assumption that banks providing liquidity services have the ability to diversify away the long-term risk of their outstanding loans, regulators have rarely been so sanguine. In general, the U.S. has depended on the existence of well-developed securities markets to supplement and in many cases replace the provision of long-term debt by commercial banks. In Japan - particularly the Japan of the high-growth era the answer has lain rather in the creation of special classes of banks whose principal sources of financing are other than individual deposits. This paper examines one such class of institution that of the long-term credit banks. 
The long-term credit banks differ from the other principal private suppliers of long-term loans in post-war Japan - the trust banks - in two major respects. One is that because they have access to fixed rate long-term financing, they have been able to make the provision of fixed rate long-term loans their principal business. Secondly, the long-term credit banks do not have an exclusive affiliation with any of the six major corporate groups which lie at the core of the main bank system in Japan. While the trust banks either lent to designated sectors or supplemented the loans of their group's city bank, and as a result have been traditionally weak in credit analysis, the long-term credit banks have built up substantial in-house credit analysis capability, and loaned across corporate groups to the principal players in major industries. ${ }^{1}$

Interpretations of the role of the long-term credit banks within the Japanese financial system have varied. In views which stress the government control over credit allocation, emphasis is placed on the governmental origins of the long-term credit banks, and the government's use of them to channel long-term funds to designated sectors. In another view more popular among economists and consistent with the above-mentioned public policy concern, the existence of longterm credit banks, along with their participation in financial consortia, has assured maturity transformation in Japan. ${ }^{2}$

'Japanese insurance companies have also provided long-term fixed rate loans to industry. At the end of 1980, life insurance companies were providing 5 trillion yen of outstanding industrial equipment loans, compared to 9.6 and 10.6 for the long-term credit and trust banks, respectively. (Bronte: 105) Like the trust banks, most insurance companies belong to an industrial group, lend principally to the firms within those groups, and are only rarely the largest lender to any particular borrower.

2For a cogent statement in English of the latter point of view, which also emphasizes the Japan Development Bank, see Sakakibara et al (1982). Although the two views are not necessarily mutually exclusive, an emphasis on the mechanics of maturity transformation does not rule out lending decisions based primarily on economic considerations. 
While both of the above interpretations have to one degree or another been correct at different intervals (the former for a more limited time period), neither explicitly places the longterm credit banks within the system of "main bank" relationships which has become a defining characteristic of the Japanese financial system. The underlying premise of this paper is that the long-term credit banks have provided an important counter-balanceto aspects of the "main bank" system which are potentially negative: namely, commercial banks tied too closely to companies may assume an inappropriately high level of risk; banks whose principal clients are based on exclusive historical groupings may pay too little attention to important unaffiliated companies, and may be unable to broker important information flows and tie-ups with companies of other groups. The existence of long-term credit banks with a neutral stance among the six bank-centered keiretsu, which bring both active and knowledgeable participation to the syndication of credits, and provide a source of main bank services to large companies outside the principal bank groups has helped to minimize the potential drawbacks to the group-oriented main bank system. In coordination with government policy, long-term credit banks have been able to provide services to entire industries in decline and transition, helping to coordinate those efforts that are required across groups.

The paper will proceed in three principal parts. In the first section to follow, we review the origins and identify in detail the important legal and institutional features which distinguish the long-term credit banks. We will concentrate in particular on the issuance of financial debentures, as the use and exclusivity of this privilege has been an central issue in long-term financing. In the next section, we survey cooperative financing by the long-term credit banks, both with the Japan Development Bank, and with the other private banks. In section 4 , we examine more closely the role of the long-term credit banks as main banks, concentrating in particular on certain aspects of the history of the Industrial Bank of Japan. We end the paper with a brief conclusion. 


\section{The Origins and Distinctive Features of the Long-Term Credit Banks.}

2.1 Origins and Rebirth. The establishment in Japan of institutions specializing in longterm credit occurred at the turn of the twentieth century, and thus postdate by a few decades the start of Japan's modernization and establishment of a modern banking system. ${ }^{3}$ Prior to their establishment, long-term funding needs had been principally met by the issuance of stock and loans from ordinary banks which were secured by the stocks of the company. These stocks in turn served as collateral for bank bills which were discounted at the central bank, guaranteeing commercial bank liquidity. Concerned that the provision of funds for fixed investment was not proper for ordinary commercial banks, and that the acceptance of corporate stock as collateral was not a proper activity of the Central Bank (IBJ, 2-3), Meiji oligarch Matsukata had long planned for the creation of special banks, but it took many years to overcome the opposition from private financiers, and to pass legislation enabling the creation of specialized long-term credit banks based largely on the French model.

The Hypothec Bank of Japan (Nippon Kangyo Ginko) was established in 1898, which supplied long-term funds to agriculture and related industries secured by real estate. ${ }^{4}$ In 1901 , the Colonial Bank of Hokkaido ( development of Hokkaido also specializing in loans secured by real estate. In 1903, the Industrial

${ }^{3}$ For a complete discussion and analysis of the development of the Japanese banking system during the Meiji period, see Patrick (1967), and the sources cited therein.

The Law governing the activities of the Hypothec Bank was passed a year earlier in 1897. Another bank, Noko Ginko, which specialized in lending to smaller agricultural businesses, was also established to specialize in loans secured by real estate. This was later absorbed into the Hypothec Bank in 1934. In addition to agriculture, the Hypothec Bank made an equal proportion of loans to light manufacturing industry (e.g., cotton textiles). (Patrick, 1967) 
Bank of Japan (Nihon Kogyo Ginko) was established to specialize in long-term loans in manufacturing and railways secured by movable property. (IBJ, 4-6; Fukuzawa, 3)

Though privately capitalized, the officers and directors of these banks were appointed by the Ministry of Finance, and thus were effectively government institutions. All three of the special banks were allowed to issue debentures as a means of long-term fund raising, most of which were purchased by the Ministry of Finance Deposit Bureau which drew funds from the Postal Savings System.

However, the emergence of these banks did not mean that ordinary banks ceased their long-term lending. The long-term banks were meant to serve as a supplement to ordinary bank lending, and while the quantity of short-term loans the special banks could make was limited, at no time was the maturity structure of the loan portfolio of ordinary banks limited by statutory regulation..$^{5}$ Nonetheless, concurrent with the industrialization of the Japanese economy, the special banks emerged as more than supplementary institutions. In particular, as government controls became more pronounced in the war economy, IBJ assumed an ever more central role in managing syndicated financing of the military buildup, a fact which has been touched on elsewhere in this volume (Teranishi; see also Table 8 of Hoshi, 1993).

The institutions specializing in long-term lending suffered a short death, at least in theory, after the Second World War during the Allied Occupation. In April 1950, all of the special banks laws were abolished and distinctions between all banks apparently eliminated. However, historical accounts relate that more than one year earlier in November 1948, IBJ had already overcome

\footnotetext{
${ }^{5}$ By contrast, the French system of long-term credit banks, upon which Japan's system was based, limited the ability of ordinary banks to make long-term loans.
} 
initial resistance ${ }^{6}$ and obtained the oral approval of occupation authorities to recapitalize as a bank specializing in long-term credit with bond issuing authority. Approval was conditioned on, among other things, restrictions on deposit-taking, and the elimination of governmental authority.

Consistent with the agreement, IBJ not only recapitalized but proceeded to raise funds under a special new law passed in 1949 which temporarily permitted IBJ to issue debentures up to twenty times capital.

Simultaneous with the abolition of the special bank laws in 1950, a new law was passed which allowed all banks to issue debentures if the sum of outstanding debentures and deposits were less than 20 times capital. Nonetheless, only the former special banks were able issue debentures since the city banks' many deposits and low capital placed them above the limit. (Kinyu Seido Chosakai Senmon linkai Hokoku, III,6) By this point, occupation authorities were clearly favoring the former special banks, as special assistance funds were used to purchase their issues of preferred stock in 1950 , in an effort to stimulate long-term financing of industry.

The 1950 law was inevitably a transitional measure. Prior to its passage, there was controversy among the Japanese over the fairness of also permitting Kangyo Bank to issue debentures when only IBJ had agreed to restrictions on individual deposits. (Ministry of Finance, 1983, 599, 603) Not only did this issue remain unresolved, but when the Bank of Tokyo proposed

This was due both to a suspicion of IBJ for its central role in the financing of the war effort and an economic judgement that long-term funds should be raised in the capital market.

This was in sharp contrast to earlier policy requiring that special banks make the choice of being either commercial banks or bond-issuing companies. Unable to recapitalize, IBJ directors in the last half of 1948 faced the danger of liquidation or absorption by another bank. The fact that Japanese government support was wavering during this period appears to have contributed to the organizational sense of IBJ as a private institution. A historical narrative is to be found in IBJ (1957: f.711), contemporaneousdocumentation in MoF (1976: 557-616); personal reminiscences in Hazawa (203-223); and drama in an generally accurate historical novel (Takasugi, Vol. 1-2). 
to issue bonds of their own in 1951, (IBJ, 1957, 893) there arose a more general concern that the indiscriminate permission to issue bonds among banks would lead to confusion and oversupply in the bond market, and adversely affect the supply of long-term finance. ${ }^{8}(\mathrm{MoF}, 1983,608)$

Meanwhile, the current economic situation was also stimulating further discussion of the the long-term credit system. In the Korean War boom in 1951, large city banks were overwhelmed by the spiralling funding needs of both their clients and those of the sectors identified by the priority production system, and had increasingly resorted to credit from the central bank to meet funding needs, a phenomenon dubbed the "overloan problem." ${ }^{m}$ In response to questioning in the Diet in February 1952, Minister of Finance Ikeda stated that the current financial system was inadequate, and suggested that the establishment of investment banks specializing in long-term finance funded by debenture issuance would perhaps be one solution to the problem. (MoF, 1983, 609)

The government set up a temporary Financial System Council consisting of representatives of industry, finance, and academia to examine further reform of the institutions for long-term credit in December 1951. After study of various proposals and debate, the Council presented recommendations in February 1952 to the Ministry of Finance (IBJ, 144-150; Ministry of Finance, 1983,610-613). Subsequent to cabinet approval, the Ministry of Finance subsequent submitted a

${ }^{8}$ Another important development affecting the future of the bank debenture market occurred during the final stages of the establishment of the Japan Development Bank in early 1951. Due to last-second objections by occupation authorities as well as the Bank of Japan, it was decided that JDB would not be granted special debenture-issuingprivileges as had been previously planned. (MoF, 1983, 145)

The four designated priority sectors were those of coal, iron and steel, electric power, and shipping. In 1952, the investment of these four industries occupied $44 \%$ of all Japanese plant and equipment investment, and $70 \%$ of all lending for plant and equipment investment from banks went to these industries. In the same year, city banks relied on Bank of Japan loans for more than $10 \%$ of their funding needs. Despite Bank of Japan assistance, city banks had beguis to withdraw loans to other corporations in non-priority sectors for the purpose of meeting the demand of the designated sectors. (Kinyu Seido Chosakai, III, 7-8) 
Long-Term Credit Bank Law to the Diet the following month.

The formal explanation accompanying the proposed law stated that that newly formed government institutions such as the Japan Development Bank could be counted on to perform only a supplementary role to private institutions in the financing of long-term investment. Specialized long-term credit banks would reduce the burden of over-extended city banks in the provision of long-term credit and further the protection of depositors. However, in order to secure the smooth supply of funds to these institutions, these banks would need to have specialized access to the funds, so the 1950 law granting all banks to issue bonds up to 20 times capital was to be abolished. (IBJ, 148; MoF, 1983, 612-613)

Significantly, the neutral status of the long-term credit banks with regard to the city banks and their particular clients was considered important at the time: It would make more efficient the allocation of long-term capital and faciliate mutually beneficial relations between the long-term credit banks and city banks. It was also viewed that neutrality would assure that any indirect government funding of priority sectors that occured through the long-term credit banks would in turn be provided to the private sector on a basis independent of any particular group affiliation. (Takenaka, 61-62) By contrast, the idea that securities markets should serve as the supplementary source of long-term debt was given little serious consideration. ${ }^{10}$

One important aspect of the plan which was discussed at numerous stages of the deliberations was how many long-term credit banks there should be. Due to economies of scale in

\footnotetext{
${ }^{10} \mathrm{~A}$ compelling argument made in Teranishi and elsewhere is that the scarcity of financial capital made impractical the dependence on securities markets for the provision of long-term capital. For evidence on the scarcity of financial capital in the Japanese economy around 1950, see Teranishi, 413-417. This also was the stated belief of the Ministry of Finance at the time of the promulgation of the long-term credit bank law in 1952. (Takenaka, 60) The postwar experience of high inflation had also left savers (investors) wary of longer-term bonds.
} 
the provision of long-term credit, and perceived limitations in the demand for bank debentures, the general opinion was that few rather many banks should be established, though a monopoly was to be avoided. In addition to IBJ, the two other former special banks were viewed as prime candidates; however, the Kangyo Bank and Hokkaido Takushoku Bank were unwilling to forgo their commercial banking business for the sake of retaining their debenture-issuingprivileges. Instead, they promised to contribute personnel and capital to a newly established long-term credit bank, and preparations for the creation of a new bank were begun with the active assistance of the financial community. (Ministry of Finance, 1983: 598, 608-616)

The Long-Term Credit Bank Law passed the Diet in June, and was enacted in December 1952, while the law permitting debenture issue by all banks was abolished. The Industrial Bank of Japan (IBJ) moved immediately to charter itself as a long-term credit bank, and simultaneously, a Long-Term Credit Bank (LTCB) was created out of the long-term lending divisions of the Kangyo Bank and Hokkaido Takushoku Bank. A third bank based on the remnants of the colonial Bank of Chosen (Korea), was chartered as a long-term credit bank in 1957 as Nippon Fudosan Bank, later renamed the Nippon Credit Bank. (NCB) Thereafter the number of long-term credit banks has been fixed for the past 35 years at three.

\subsection{The Long-term Credit Bank Law (1952)}

\subsubsection{Provisions Constraining the Scope of Business. The scope of business which} the long-term credit bank may perform is limited by Article 6 of the Long-Term Credit Bank Law. Its principal business is defined to be the making of loans, discounting of bills, acceptance of bills, and provision of guarantees with regards to long-term working capital or plant and equipment 
capital. ${ }^{11}$ (Art. 6.1.1) Long-term credits (defined as longer than six months) for other purposes may be provided only if they are secured by real estate (Art. 6.2), and short-term credits for any purpose may be provided only to the extent they do not exceed the total of the bank's deposits or similar accepted money. By contrast, the city banks are not limited by law in their mix of long and short-term finance. (Table 1)

The limitation on short-term finance to the quantity of deposits is made the more binding by the fact that unlike the city banks, long-term credit banks in principle are not to be deposittaking institutions. The acceptance of deposits is limited to borrowing customers, companies for which the bank acts as trustee, and government institutions. (Art. 6.1.3)

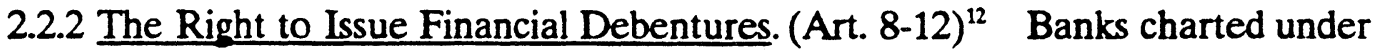
the long-term credit bank law are granted compensation for the above constraints in the form of the right to issue long-term financial debentures with a maturity of 5 years. ${ }^{13}$ These coupon debentures, combined with the prevention of the creation of deposit instruments of similar length by the city banks, ${ }^{14}$ has been central to the segmentation of short and long-term finance in Japan.

\footnotetext{
${ }^{11}$ In addition to the provision of credit, a long-term credit bank may act as a trustee for the flotation of local and corporate bonds, and perform foreign exchange transactions (Article 6.1.4-5), rights which the city banks also possess.

${ }^{12}$ Those readers desiring a more complete English language overview of the bank debenture market are referred to Doi (1990).

${ }^{13}$ Since November 1991, the long-term credit banks, as well as Norinchukin and Shoko Chukin Bank, have also been allowed to issue 2-year bank debentures. This was part of a larger liberalization policy which granted city banks permission to sell 3-year large-lot time deposits.

${ }^{1}$ The allowed term of the fund procurement of the city banks has only been gradually lengthened. A two-year term deposit was approved in 1971, a three year quasi-term deposit (with the right to withdrawal after one year) in 1981, and a large-lot 3-year deposit in 1991. Loan trusts, the principal source of lendable funds for the trust banks, come in five year maturities, but operate as variable-rate instruments.
} 
The long-term credit banks may also issue discount debentures which are 1 year in maturity. Both coupon and discount debentures are issued on a monthly basis, and are granted numerous forms of preferential treatment to assure smooth issuance and a secure source of funds. (Table 2) ${ }^{15}$

Article 8 allows debentures to be issued within the limit of an amount of 30 times $^{16}$ the total of capital and reserves, far larger than the two times capital limit stipulated for ordinary corporate debentures. These bonds, unlike those of the great majority of Japanese corporations until recently, may be unsecured. The bonds are bearer bonds unless otherwise requested (Art. 11.2) which gives them added liquidity, and has facilitated their use as collateral for call money and Bank of Japan borrowings.

Issuing procedures are also much simpler than those required for ordinary corporate bonds. While ordinary corporations cannot start subscription until application is submitted to and approval granted by the Ministry of Finance, bank debenture issuers only have to report the amount and terms. ${ }^{17}$ (Art. 10) Article 11 provides the issuers of financial debentures with another advantage: the capability for reduced issuance (gengaku hakko). While according to the Commercial Code, ordinary corporate bonds issues must be called off when the amount subscribed does not reach the total amount of the issue, financial debenture issues can be adjusted downward depending on the level of subscription, which permits a continuous issuance of financial debentures regardless of

\footnotetext{
${ }^{15}$ In addition to the long-term credit banks, three other institutions are allowed to issue financial debentures: the Central Cooperative Bank for Agriculture and Forestry (Norin Chuo Kinko), the Central Cooperative Bank for Commerce and Industry (Shoko Chukin Chuo Kinko), and the Bank of Tokyo. The first two of these banks provide funds primarily for small farms and businesses. The Bank of Tokyo's coupon debentures may have a maturity of only 3 years.

${ }^{16}$ The original limit of twenty was raised in 1981.

${ }^{17}$ This parallels the practice in the U.S. bond market of "shelf registration," a privilege which has been granted since 1981 to all U.S. issuers of corporate bonds.
} 
unexpected financial conditions.

Finally, bank debentures, unlike other corporate bonds, can be sold without subscription ( and obtain the certificates immediately upon payment. This allows purchasers to forgo the preparation of application forms, and promotes sales to the general public. Approximately $70 \%$ of coupon and all discount debentures are sold in this manner.

2.3 The Evolution of the Primary Market for Financial Debentures. The rates on issued coupon debentures are set by an informal cartel consisting of the long-term credit banks, the three other institutions which issue bank debentures, and the trust banks. ${ }^{18}$ Changes in the rate follow close consultation with the Ministry and Finance and the Bank of Japan. Since the introduction of a long-term prime rate as the standard minimum rate for long-term loans, the long-term prime has been set at a fixed spread over the debenture rate. ${ }^{19}$

Given the fixed spread and the existence of excess demand for long-term investment financing during the high-growth era $^{20}$, the profitability of the long-term credit banks depended on

${ }^{10}$ Trust banks are included in the negotiations as the prospective dividend rate on trust certificates offered by the trust banks is fixed at 2 basis points above the prevailing bank coupon rate. The actual rate of return on trust certificates is variable. (Pressnel, 225) Over time, secondary market yields on debentures have also come to play a role in determining a prime rate change, and now the coupon rate (and thus the long-term prime) is usually revised when the lowest yield on the debentures differs by 0.2 percentage point or more from the coupon rate.

${ }^{19}$ This spread started at $1.4 \%$, moved to $1 \%$ in 1966 , and has been fixed at $0.9 \%$ since 1968 . Though traditionally the long-term prime has served as the lower limit for long-term lending, since the mid-80s, discounts from the long-term prime have become less exceptional. (Suzuki, 146-147) In April 1991, city and regional banks began to set individually their own long-term prime rates (linked to the short-term prime), at rates significantly higher than those charged by the long-term credit banks.

The well-known city bank practice of rolling over short-term loans suggests that firms desired more long-term credit than they got; for other evidence that the long-term credit market was out of equilibrium, see Teranishi, 505-515. 
the successful issuance of coupon debentures. However, as an integral part of the structure of regulated interest rates, ${ }^{21}$ the coupons on financial debentures did not reflect equilibrium rates. The subscription rate was below market rates - not only well below the short-term call rate (Shimura, 1980: 219), but consistently below the yield on bank coupon debentures in the secondary markets. (Teranishi: 455-456) In such an environment, the generation of demand in the primary market for coupon debentures was not a trivial issue.

2.3.1 The Era of Trust Fund Bureau Purchases. In the early fifties, the long-term credit banks depended principally on the debenture purchases of the Trust Fund Bureau (Shikin Unyobu) of the Ministry of Finance. Between 1952 and 1955, the Trust Fund Bureau bought close to $50 \%$ of issued coupon debentures. (Exhibit 1)

However, the dependence on the government as the principal purchaser of coupon bonds was destined to be short-lived. In June 1955, the Trust Fund Bureau temporarily ceased the purchase of new issues, and requests were made by the Ministry of Finance to the local and city banks to compensate with an increase in their own purchases. Reasons for the withdrawal of Trust Fund Bureau participation included the increased burden of purchasing municipal bonds, and the funding of public corporations and the Japan Development Bank. (IBJ: 221-222; Sup. Vol.: 372).

Although the Trust Fund Bureau continued to refinance their previous purchases and would from time to time make new purchases of financial debentures explicitly tied to sector-specific

\footnotetext{
${ }^{21}$ See Teranishi for detailed description and analysis of the structure of regulated interest rates during the high-growth era. (451-506)
} 
loans, ${ }^{2}$ the ratio of their purchases to all coupon debentures issued sharply declined to below $10 \%$ of all issues by 1959 , and after a resurgence to $10-20 \%$ levels in $1961-63$ declined to single digit levels thereafter.

\subsubsection{The Purchases of City Banks and Other Banking Institutions. Accompanying} the decline in the importance of Trust Fund Bureau purchases, purchases of issues increased by private banks, in particular the city banks. Between 1956 and 1965, city banks averaged $45 \%$ of all purchases of issued coupon bonds. (Exhibit 1) Three principle factors were responsible:

(i) Regulation of Deposit Rates. Although the rates of interest on bonds were not as great as what a city bank could have received in providing long-term funds to a company, they were nonetheless always substantially above regulated time deposit rates. This enabled banks to hold bonds at a profit despite their low rates of interest. (Shimura, 1980: 230) (ii) Cooperative Financing. (yocho Yushi) A practice evolved whereby city banks could expect financing for their preferred customers from the long-term credit banks in return for their purchases of the coupon bonds. Apparently, a rule of thumb was for the longterm credit banks to make loans to the city bank's preferred customers of approximately double the amount of bond purchases of that city bank. (Patrick, 1972: 125) City banks could also expect a flow back of deposits from customers able to obtain financing from the long-term credit banks. (Shimura, 1980: 254) A similar sort of mechanism was at work encouraging the debenture purchases by the smaller regional banks. In compensation for purchasing bonds, they would be

${ }^{2}$ For example, a 1958 purchase of 10 billion yen of long-term bank debentures by the Trust Fund Bureau went to long-term loans to steel and shipping in a predetermined 40/60 ratio. (IBJ: 348). In 1961 another purchase of 5.5 billion yen (followed by 3 billion yen in 1962) occurred for the funding of electric power and steel. In 1963, there followed a purchase of bonds tied to 6 billion yen of loans to the machine tool industry. (541). 
made the agents of long-term credit bank loans to customers in their local region. ${ }^{23}$

(iii) Access to Bank of Japan Credit. Financial debentures could be used as collateral for Bank of Japan loans upon which city banks remained heavily dependent. ${ }^{24}$ When the Bank of Japan shifted its emphasis to market operations in the early 60 's as a means of supplying liquidity to the system, coupon debentures were made one of the categories of eligible paper. Thus, as rates in the secondary market meant that issues could be disposed of only at a loss, it was Bank of Japan policy which made the debentures liquid and encouraged the use of coupon debentures by city banks as a reserve instrument. Further, the fact that credit from the Bank of Japan was substantially below market rates implied that the costs of coupon debenture purchases could be effectively recouped in the form of Bank of Japan subsidies. ${ }^{25}$

${ }^{23}$ Shimura, 1980: 255. Further discussion of the agency loan system is in part 3 of this paper. Government policy also played a role in financial debenture purchases by regional banks and other financial institutions. When city banks were less willing to buy debentures during tight money periods, the government would encourage the local banks to turn away from the call money markets and buy more financial debentures. (IBJ: 545) To provide further incentives for diversification of the long-term banks' fund sources, sogo banks and credit cooperatives were allowed to be representatives of agency loans in 1954 and 1959, respectively.

${ }^{24}$ As of June 1964, more than $40 \%$ of the outstanding Bank of Japan loans were collateralized by financial debentures. (Takenaka: 72)

${ }^{x}$ Ironically, while long-term credit banks were in part created to cure the "over-loan problem," city bank dependence on the Bank of Japan credit was systematically related to the fund supply of the long-term credit banks during this period. Teranishi has documented that for 1966-1977, Bank of Japan subsidies to city banks were approximately equal to what they passed on to all bond issuers in terms of the purchase of overpriced bonds. Approximately $45 \%$ of the estimated "tax" of aggregate bond holdings was due to the holdings of financial debentures, a figure which undoubtedly was greater during the early stages of the high growth period. (483-489) 


\subsubsection{Discount Bonds and the Increasing Importance of Individual Investors. ${ }^{26}$ While}

financial institutions were the principal purchasers of coupon debentures during the high growth era, individual investors were being courted as purchasers of one-year discount bonds. ${ }^{27}$ The importance of discount bonds during the high-growth era should not be underestimated.

Constituting between $20-30 \%$ of the outstanding volume of all financial debentures (Exhibit 2), they served the role of a buffer to changes in demand for coupon debentures, and stabilized the overall quantity of funds that could be raised by the long-term credit banks. In times of monetary tightening, when city banks would cut back on their purchases of coupon debentures, the long-term credit banks would meet funding needs by increasing the sales of discount bonds. (Shimura, 1980: 227-229)

The rate on discount bonds was set at exactly the same level as one-year time deposits. What made them even more attractive in 1955 was the introduction of a system in which securities companies were allowed to borrow for a fee the discount bonds of their customers, which they would then use as collateral in the call money market to finance stock purchases. (Unyo Azukari, or "use trusts") In 1965 , nearly $85 \%$ of all oustanding discount bonds had been sold through securities houses. ${ }^{28}$ (Exhibit 3)

However, the unyo azukari system was abolished in 1965 when it become clear that

\footnotetext{
${ }^{2}$ In the Japanese bond statistics, the category of individuals is aggregated with that of nonfinancial corporations (and foreign investors). In practice, many corporate purchasers are wealthy individuals who both own and manage a small or medium-sized company, so the use of the term "individual" is not as misleading as it may seem. A recent case in point is the purchase and now infamous misuse of IBJ discount debentures by restaurant owner and proprietress Nui Onoue.

${ }^{27}$ Discount bonds can be traced back to a 1920 financial crisis when issuance was allowed IBJ to assist in the undertaking of emergency financing to distressed companies. (IBJ: 38)

${ }^{28}$ Inflation also gradually increased the attractiveness of the discount bonds, by bringing the 10,000 yen unit within the reach of individual investors.
} 
Yamaichi Securities had become insolvent and an industry crisis precipitated in no small part through abuse of the system. (Adams and Hoshii: 170-172) New measures were needed to increase the marketability of discount bonds. In 1967 , the rate on discount bonds was lifted to a few basis points above the one-year time deposit rate. The same year, a new tax system was introduced whereby taxes on coupon bonds were limited to a $5 \%$ withholding tax upon issuance, which compared favorably with the withholding tax rate on interest income and dividends of 15 $20 \%$.

Another important transition in the discount bond market followed the gradual expansion of the long-term credit banks own retailing efforts. The long-term credit banks, which distributed only $15 \%$ of their own discount bonds in 1965 , had raised that proportion to more than $50 \%$ in 1985. By 1985, the proportion of discount bonds among outstanding financial debentures had increased to more than 35\%. (Exhibits 2-3)

While individual investors have consistently accounted for more than $95 \%$ of the purchases of the discount bond market, a more recent development is their occupation of the principal investor category for coupon debentures (Exhibit 1). The decline in the role of city banks in this market was set off by the issuance of government bonds in 1966 . City banks dramatically slowed down their purchases of new bank debentures, both because of the burden placed on them to underwrite government bonds, and because the Bank of Japan removed financial debentures from their open market intervention account. The attractiveness of coupon bond purchases having been drastically reduced, in 1967 city banks started actively selling large quantities of their holdings of outstanding bank debentures. (IBJ, 732-734) The decline in their relative holdings has been steady 
since the mid-60's, and now approaches only $5 \%$ of outstanding issues. ${ }^{29}$

On the other hand, local banks and other financial institutions, which never were as dependent on Bank of Japan financing as the city banks, and unlike the city banks have generally had more funds than lending opportunities, maintained their relative proportion of financial debenture purchases even after the end of the high-growth era.

The decline in sales to city banks has been made up through large increases in the sale of coupon debentures to individuals. (Exhibit 2) Some factors behind these increases have been taxrelated: most recently the search by savers for alternative instruments in the wake of the elimination of the Maruyu system..$^{30}$ Marketing efforts have also intensified: in 1981 a new and very popular type of coupon debenture was introduced by the long-term credit banks, which effectively was a zero-coupon debenture. ${ }^{31}$ One IBJ strategy has been to go after the savings of workers of their large corporate clients such as Hitachi and Kansai Electric. (IBJ: 1076-1079)

An important feature of discount and coupon bonds for some individual investors has been that they are in bearer form, and can be purchased anonymously. This facilitates the evasion of estate and income taxes; ${ }^{32}$ further, the purchase of financial debentures can be used as a means of laundering illicit income. However, in response to public concern, measures have been recently

${ }^{29}$ Another factor behind the city banks' withdrawal from the bank debenture market since the early-70's has been the active pursuit and use of funds for new lending opportunities in the small and medium-sized business sector.

${ }^{30} \mathrm{Also}$, in 1974 , the maximum amount of debenture holdings whose interest could be exempt from income taxation was raised from 15 to 30 million yen.

${ }^{31}$ Called "wides", the interest on these instruments is compounded semi-annually, and one complete payment made upon maturity.

${ }^{32}$ Around $10 \%$ of the 221 billion yen in concealed income identified in tax-evasion cases filed by the National Tax Administration Agency between 1989-1991 was accounted for by financial debentures. (Nikkei Weekly, 3/15/93) 
taken to curb the abuse of the anonymity feature of financial debentures..$^{33}$

The maintenance of a steadily growing demand for financial debentures has been a significant achievement for the long-term credit banks, particularly since the decline in city bank purchases and the emergence of significant competition in the form of government debt. Though they now share the spotlight with government bonds, financial debentures retain a dominant share of the Japanese bond market. (Exhibit 4) This achievement has been the result of important tax and regulatory changes at critical moments of transition in the market, intensified marketing efforts by the institutions themselves, and the full exploitation of those advantages originally given to financial debentures in the 1952 law, as well as the continued repression of competitive instruments such as longer-term deposits or five-year corporate bonds.

Will this form of financing persist as an effective source of funds for long-term credit banks as more competitive instruments emerge as part of efforts to deregulate the financial system? Although developments in the secondary market may lead to differing costs of capital among the long-term credit banks in line with their credit ratings, ${ }^{34}$ the history of Japanese regulatory practice suggests that any systemic damage done to the fund-raising capabilities of long-term credit banks by

\footnotetext{
${ }^{33}$ The Finance Ministry issued a directive in 1990 to financial institutions which required that they confirm the identities of clients involved in transactions of more than 30 million yen. The Kanemaru case, in which at least a few billion yen of undeclared political donations were used to buy discount bonds, suggests that further reform may be necessary. Kanemaru had been able to circumvent the new identification rule through the cooperation of a securities company which divided his purchasing orders into small lots which were bought from different bank branches.

${ }^{3 *}$ Throughout the post-war era, the long-term credit banks have issued their financial debentures at identical coupon rates, a process supported in the secondary market by identical yields. However in June 1992, there emerged significant gaps in the market yields of the five-year debentures of the three long-term credit banks, reflecting in particular worsening news about the condition of NCB's non-bank affiliates. Given common coupon rates, future subscription to NCB issues by major investors such as insurance companies are likely to occur at discounts from par, implying a higher cost of capital. Whether this condition is temporary or not depends for the most part on the rehabilitation of NCB.
} 
liberalization measures will be gradual, and compensated for by relaxed restrictions of their own activities in other areas. ${ }^{35}$

The next section of this paper shifts focus to the asset side of the long-term credit banks' balance sheet. How has their steady growth translated into patterns in the financing of corporate clients? And what role have they come to play within the Japanese main bank system, either as participants, or as lead banks themselves?

III. Cooperative Financing of the Long-Term Credit Banks

To a greater degree than the other large banks in the Japanese financial system, the longterm credit banks have been involved in two types of joint, cooperative financing. First, they have worked with government financial institutions, particularly the Japan Development Bank, in policyoriented financing projects. Second, they have provided supplementary long-term finance to leading companies in all of the enterprise groups, as well as those few not so affiliated.

3.1 Cooperative Financing with the Japan Development Bank. During the period when the Trust Fund Bureau was the principal purchaser of financial debentures, most of the funds supplied by the long-term credit banks were targeted to the designated priority industries of coal mining, steel, electric power, and shipping. The principal partner of the long-term credit banks in

${ }^{35}$ See footnote 13. The case of the government bond market suggests that new entry into the bond markets can be managed to increase the overall market more than cut into the debenture issues of the long-term credit banks. As for the loss of borrowers that further development of the corporate bond market may entail, long-term credit banks may well be compensated by an increased growth in their fees from bond underwriting and trading of straight bonds, privileges granted in 1993. 
this activity was the Japan Development Bank (JDB). Of the nearly three hundred billion yen in loans supplied by JDB to industry between 1951 and 1956 , nearly $85 \%$ went to the priority sectors. (JDB, 1993: 167) In 1956, of the outstanding plant and equipment loans to these sectors by city banks, long-term credit banks, trust accounts, and JDB, the JDB accounted for nearly $45 \%$, as compared to $30 \%$ for the long-term credit banks. (IBJ: 203-208) Among the priority sectors, funding from the long-term credit banks was greater only in steel. (Table 3)

However, even during its early history, the role of the Japan Development Bank in determining the direction of Japan's credit flows should not be overestimated. Unlike its predecessor, the Reconstruction Finance Bank (RFB), the Japan Development Bank was not allowed to provide working capital loans, which often made loans in coordination with private banks a necessity. In addition, the legal mandate of JDB actively encouraged cooperation with the private banking system. ${ }^{36}$

Another relevant point is that in its early years as a nascent institution, JDB relied heavily on the expertise in credit analysis of staff and directors seconded from other financial institutions, particularly IBJ. The Reconstruction Finance Bank had in fact been founded as a division within the Industrial Bank of Japan in August 1946, and a total of 127 personnel were seconded from IBJ during its brief lifetime. (MoF, 1978, 627-631; IBJ, 106) In addition to some personnel carried over from the RFB, upon its formation the JDB depended further upon the expertise of staff and directors seconded from the Industrial Bank of Japan, as well as the Kangyo Bank and the Bank of

${ }^{36}$ Article 22 of the Japan Development Bank Law states that "... the Japan Development Bank shall not compete with banks and other financial institutions with respect to its business operations." In an internal JDB memo dated April 1952, it was stated that since JDB credit was intended to supplement private bank funding, JDB should "actively undertake cooperative financing" with the private banks. (JDB, 1976: 55) 
Japan. $^{37}$

In addition to steel, the long-term credit banks were the principal lenders for investment in the other important manufacturing industries such as machinery, chemicals, textiles, cement and ceramics. In fact, the establishment of the long-term credit banks was a principal reason that the financing to industries other than the priority industries fell from $20 \%$ of JDB loans in the early fifties to $10 \%$ in the mid-fifties. According to JDB historians, there was a reduction in the number of industries targeted for funding by the JDB starting in 1953 "because the enactment of the LongTerm Credit Bank Law had resulted in the inauguration of private long-term financial institutions which could devote themselves to the long-term financing of the remaining industries." (JDB, 1993: $163,167)$ Long-term credit banks provided more than twice the funds of JDB in those "nonpriority" manufacturing industries in 1956 , and nearly five times as much 10 years later. ${ }^{38}$

The company-specificloan data presented in Table 4 yield similar implications. We see a strong correlation of JDB activity with that of the long-term credit banks: of the 161 listed companies which had a long-term credit bank in 1967 as the largest private lender, ${ }^{39}$ nearly $50 \%$

\footnotetext{
${ }^{37}$ In all, nine individuals including two division chiefs and one section chief were seconded from IBJ to the Japan Development Bank upon its formation. A tenth individual, Sohei Nakayama, the future president of IBJ, served as a director. Combined with secondments from the Kangyo Bank and the Bank of Japan, 27 out of the $\mathbf{4 6}$ male employees (not including directors but including 11 division and section chiefs) of the newly-established JDB were appointed from outside institutions. (Takasugi: 3,50; IBJ, 139; JDB,1976:44; JDB,1993:154)

${ }^{38}$ Although JDB loans towards other industries began to increase again in the late 50's (JDB, 1993: 180-181), its concentration in the priority sectors in relation to other banks did not change. The significant proportions of JDB funding which went into relatively declining industries such as coal mining and shipping in the 60 s and 70 s parallel those proportions for all government funding discussed in Hamada and Horiuchi: 243.

${ }^{39}$ To avoid overestimating the importance of the long-term credit banks, we will determine company's "lead lender" by aggregating the loans of all financial institutions in the group. Thus, a long-term credit bank can be a lead or primary lender only if its loan share exceeds that of each keiretsu's aggregate loan share.
} 
were also obtaining loans from the Japan Development Bank. ${ }^{40}$ However, in terms of both numbers of firms and the average loan shares, JDB loans were concentrated more heavily than those of the other banks in the three areas of mining, electric power, and shipping. In the latter two industries, JDB lending averaged more than 3 times that of the leading long-term credit bank, and JDB was the lead lender in 16 out of 18 cases. But in the other manufacturing industries, the JDB share averaged one-third to one-fourth that of the leading long-term credit bank.

Divergence was further accelerated in the mid-1960s when JDB expanded its lending for social welfare projects such as regional infrastructure. (JDB, 1976: 285-286; JDB, 1993: 198-199) The two principal areas of JDB and long-term credit bank cooperation remain shipping and electric power.

Given that the largest lender to a number of the companies in these two industries is JDB rather than the long-term credit bank, some might interpret JDB as the main bank. ${ }^{41}$ However, they would be mistaken, for by all the remaining criteria by which the main bank relationship was defined in Chapter 1 of this volume, the JDB-firm relationship is either non-existent or weak. By statute, JDB is not allowed to own firm shares, provide bond-issue related services, or maintain corporate deposit accounts. Finally, though personnel are occasionally seconded to client companies, a leadership role in corporate rescues is absent from its history, in all likelihood ruled out by the above-mentionedinability to provide working capital finance.

The above limitations are hardly flaws; in fact, the rather narrow role of JDB can be considered part of a successful development bank design based on the precautionary desire to avoid

${ }^{\infty}$ An additional $20 \%$ of the Table 4 sample had no JDB loans but financing from other government institutions such as the Export-Import Bank.

${ }^{4}$ The JDB is also the largest lender to a number of other companies in other industries such as All Nippon Airways. 
the political and inflationary aspects of the RFB experience. Although JDB loans usually have the longest term and are thus junior in the sense of maturity, they often appear to be treated on a senior basis compared to private bank credit in times of financial trouble (JDB, 1993: 134; see also Part 4.5.2) In the fifties and early sixties, JDB maintained a write-off ratios of bad loans less than both IBJ and ordinary banks. (JDB, 1993: 135) Although superior abilities in credit analysis is one possible reason, at least part of the performance of JDB loans appear to be related to their status in terms of collateral: JDB has often been given the first rank of priority on hypothecs in cooperative financing ventures. ${ }^{13}$

\subsection{Cooperative Financing with the Group Banks. Corporations, both in Japan and} elsewhere, particularly when they exceed a certain size, tend to spread their borrowings among a number of banks. This is hardly inconsistent with the existence of a main bank with specialized monitoring capabilities: there are many reasons, not mutually exclusive, and many have been discussed elsewhere in this volume. ${ }^{4}$ Statutory regulations further limit the provision of loans by a bank to single large customers - although in Japan only since 1974. (Table 1)

${ }^{12}$ For a informative table comparing differences of the RFB and JDB across a variety of characteristics, see JDB, 1993: 156; for a history of JDB's establishment see the same source, 154160 , and MoF, 1983, 95-159. For a detailed historical examination and comparative analysis of the performance and roles of development banks in Japan (including IBJ), see Yasuda, 1993.

${ }^{4}$ In their book on credit and security in Japan, the two cases that Tanikawa et al cite which involve the Japan Development Bank both had the JDB hypothec being of the first rank among the loan claims. (113,115) JDB historians also imply that it was not unusual for JDB to "demand a superior mortgage ranking in light of the collateral value," see JDB, 1993: 267. In general, securing loans with collateral is a practice encouraged by the Japan Development Bank Law, which states that all granting of credit "be deemed to be reliable" (Art 18-1-2), and the Statement of Business Methods, Article 6 of which states that all loans should be secured by real estate, floating mortgages, or other collateral whenever possible. (JDB, 1976: App., 36)

${ }^{4} \mathrm{~A}$ reason particularly relevant to the U.S. system where the securitization of loans has advanced is differing costs of capital among banks. (Gorton and Pennachi: 1990) 
In the case of Japan, another clear motivation for the division of loans to specific companies was set in place by the Long-Term Credit Bank Law. Based upon the principle of specialization of long-term finance, it encouraged companies, regardless of group affiliation, to depend on the long-term credit banks for much of their long-term funding needs. ${ }^{45}$ And through the preferential treatment of financial debentures outlined in part 2, it encouraged group banks to participate actively in this arrangement.

The role of long-term credit banks as an independent and supplementary source of longterm funds to the leading firms across bank groups grew in importance during the period corresponding to the city banks' preeminence as debenture purchasers. From 1956 to 1960 , the long-term credit banks went from providing $34.4 \%$ of new term loans for plant and equipment investment to $40.6 \%$ (from $6.7 \%$ to $11.4 \%$ of all new loans). Meanwhile city banks dropped from providing $29.5 \%$ of new loans for investment to $17.6 \%$. (IBJ, 334). In fact, during this period the net increase in city banks' coupon debenture purchases was nearly three-quarters the increase in city banks' own lending for plant and equipment investment. Especially in the heavy manufacturing industries, city banks were increasingly allowing the plant and equipment investment needs of their largest customers to be met by the long-term credit banks. (IBJ: 341-343).

More direct evidence of this phenomenon can be found in the specific loan details concerning bank and company loan quantities provided by Keiretsu no kenkyu. Exhibit 5 outlines the distribution of outstanding loans to firms listed on the first section of the Tokyo Stock Exchange in 1965 by each of the 6 major keiretsu banks and the 2 largest long-term credit banks.

\footnotetext{
"Toshihiro Horiuchi has looked into the breakdown of long and short-term loans by both company and bank for specific companies in his study of bank-firm relationships in the synthetic fiber industry. (1990) Out of nine companies in 1989, only one had IBJ as an overall lead lender. However, six had IBJ as a principal long-term lender, indicating the particular importance of IBJ's supplementary role in the synthetic fiber industry.
} 
While more than $40 \%$ of IBJ's first-section corporate loans and over $50 \%$ of LTCB's loans were directed to firms of one of the 6 keiretsu groups, the percentage of loans of the group banks to companies in the other groups varied between 15 and $30 \% .^{* 6}$

The same distinctions are to be found in sharper relief in Exhibit 6: IBJ was the second lender for 78 of the companies listed on the first section of Tokyo Stock Exchange in 1967, in comparison for an average of 44 for the six group banks. The Long-Term Credit Bank of Japan (LTCB), which in terms of loan quantity and companies to which it was the lead lender was and remains at a second tier below the group banks, "was still the second lender in more cases than all but IBJ. Even the Nippon Credit Bank (NCB), with only 4 companies to which it was the lead lender, was the second largest lender for more than 28 companies.

Not only did the long-term credit banks loan across city bank groups, but they did so in a more even fashion. For instance, while the lowest percentage of lending by IBJ to the companies of any one group was $5.8 \%$, Sanwa financial institutions lent only $3 \%$ of their funds to Sumitomo group firms, Sumitomo financial institutions lent only $1.2 \%$ of its funds to the Dai-Ichi group firms, and Mitsui financial institutions lent only $2.7 \%$ of its funds to Mitsubishi companies. (Shimura, 1978: 161)

Just as JDB loans appear to be compensated for their longer and more favorable credit terms with seniority in terms of collateral, loans provided by the long-term credit banks appear to

${ }^{4}$ At this time, the sixth group was Dai-Ichi (the merger with Kangyo bank occurred in 1971). Interestingly, the percentage of loans applied to companies within the group was noticeably smaller in the bank groups of Fuyo, Sanwa, and Dai-Ichi (40-49\%) compared to the older ex-zaibatsu industrial groups of Mitsui, Mitsubishi, and Sumitomo (57-70\%). This is consistent with studies which have found the former bank groups more loosely knit across a wide variety of measures. For a review of measures and evidence that less "coherence" implies more serious agency problems in financial contracts, see Hoshi and Ito, 1991.

Thefer to discussion and evidence of section 4.1. 
have been compensated for their additional maturity risk ${ }^{48}$ with a greater proportion of security on real estate and floating mortgages. Exhibit 7 compares the fraction of IBJ loans secured by real estate and floating mortgages with the similar proportion of all bank loans published in the aggregate figures of the Bank of Japan Economic Statistics Annual. Throughout the 60s the IBJ percentage remained in the $60-70 \%$ range, two to three times the national average. ${ }^{49}$

The use of collateral to secure loans is common among all financial institutions in Japan, and has served to protect against both risk and morally hazardous actions on the part of the borrower. $^{\text {so }}$ The relatively more common practice of securing credit by long-term credit banks may be in part responsible for write-off ratios of bad loans consistently lower than those of ordinary and

${ }^{48}$ According to rough estimates, the average period on outstanding loans in 1965 for the longterm credit banks was 4.8 years, compared to 2.9 years for the city banks, and 11.3 years for JDB. (JDB, 1993: 132)

"This is likely related to the fact that a high proportion of IBJ loans were fixed loans for plant and equipment, which naturally served as the collateral. The difference remains, though at a somewhat lower level, if we include loans secured by stocks and bonds and the "other security" category (e.g., $69.8 \%$ vs. $45.7 \%$ in 1970). By contrast, long-term credit bank loans depend much less on third-party guarantees than average (e.g., $23 \%$ to $9.4 \%$ in 1970). Although some institutions regard guarantees as more valuable than mortgages (Corbett: 43 ), the value of any guarantee will vary greatly depending on the quality of the guarantor. Since guarantors can vary in quality from the main bank to a related company (in 1975, $7.7 \%$ of corporate bankruptcies in Japan were caused by allied business failures; Ballon and Tomita: 72) to the president or important shareholder, the relative value of a guarantee versus a mortgage will will differ from case to case. In the account of Tanikawa et al, the use of guarantees usually involves directors or major shareholders. Often there is little examination of the creditworthiness of the guarantor, and a guarantors' role is "frequently seen as providing merely another source of pressure on the debtor to honor his obligations." (51-52).

so The "collateral principle" became an important feature of the Japanese financial system in the twentieth century, and its development has been described in Suzuki (1987:43-44). Along with main bank relationships, it has been called by JDB historians a "systemic characteristic" of the Japanese financial system, and has been expressed as follows: "With the goal of safe transactions in mind, in principle important financial transactions, such as corporate bond issues, bank loans and interbank transactions, will be secured with collateral." (1993: 137). 
trust banks. ${ }^{\text {S1 }}$ (JDB, 1993: 135) In addition, in the case of a group firm with outstanding debt of mixed maturity, the greater security puts the long-term credit bank in a stronger bargaining position vis-a-vis main bank lenders if the firm runs into trouble. ${ }^{52}$ Any reorganization plan involving the disposition of those secured firm assets either must pay the secured creditors back at least the value of the assets, or obtain the approval of those with senior claims on the assets. And in cases where the main bank chooses to let the firm go under, the long-term credit banks, by virtue of their senior claim to collateralized assets, are likely to recover the most from the disposal of the firm assets. ${ }^{53}$

By 1979, the proportion of long-term credit bank loans secured by real estate and floating mortgages had declined to 1.5 times the national average. This was related to a growing convergence of city and long-term credit bank loan composition by both term and purpose. As investment demand declined after the high-growth era, the long-term banks began to lend more on a short-term basis. And city banks, spurred by both the gradual (though incomplete) lengthening in

\footnotetext{
${ }^{51}$ As with JDB, superior capabilities in credit analysis may also be a factor behind the lower write-off ratios.

${ }^{52}$ This contrasts with the situation in the United States, where long-term debt is generally provided by a bond market consisting of atomistic investors. Though recent modeling of the debt maturity choice based on the U.S. environment has explained this structure by motivating the power of better informed banks both to make the refinancing decision and dilute the value of the public's long-term debt claim (Diamond, 1991), the case of Japan's long-term credit banks suggest that limitations on the ability to dilute long-term claims have been viewed as desirable in the highgrowth environment of postwar Japan.
}

${ }^{53}$ Secured claims are generally treated favorably by Japanese bankruptcy law. (Packer and Ryser, 1992) Especially in the mid-60s, a time of a number of large corporate bankruptcies, IBJ played a major role in the handling of bankrupt corporations to which they were not the principal lender, most notably Sanyo Special Steel. (IBJ: 531-532) Thus, the existence of secured claims by long-term credit banks may provide a complementary explanation to implicit contracting models discussed in this volume in which the main banks are motivated to act "as if" they were junior to other lenders in times of distress. 
the term of their deposits, and a drive to supply the investment needs of small and medium sized customers, started to direct longer-term loans toward plant and equipment investment. (Exhibits 8 and 9)

In regards to loans for investment financing, the convergence of proportions of the two classes of banks is now complete. However, as is evidenced by Exhibit 6, this convergence does not appear to have resulted in the sharp decline of the long-term credit banks (IBJ in particular) as secondary lenders. Although in the high growth period, city banks acted in concert with the longterm credit banks in part because they had to, the provision of loans to the same customers by the city and long-term banks appears to have outlived its original motivation.

\subsection{Cooperative Financing with Smaller Financial Institutions. As financial institutions} other than the city banks were important purchasers of debentures, it follows that cooperative relationships on the lending side also emerged in part to compensate these institutions for their purchases.

One mechanism was the common use of what were known as agency loans, which constituted $12 \%$ of all outstanding long-term credit bank loans in 1969. (IBJ: 861) Long-term credit banks had the right to make long-term loans to regional customers through the branches of local banks, mutual banks, and credit cooperatives. The incentive for the smaller banks was both to obtain long-term financing for their preferred customers, and to collect the fixed rate commissions as the "agent" for a long-term credit bank loan. Although the system gave the long-term credit banks the incentive to supply long-term funds to smaller firms in outlying areas despite their relative lack of branch offices, the well-known links to debenture purchases has been at times a concern among policy-makers. ${ }^{\text {s4 }}$

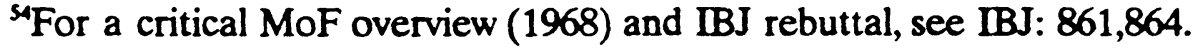


Another indirect benefit to debenture purchases was that the long-term credit banks would give preferred regional banks highly sought-after invitations to participate in large loans to prestigious customers. For instance, a large part of a syndicated loan to Hitachi was dispersed by IBJ to more than 20 local banks in the late 50s. (IBJ: 336)

\section{The Long-term Credit Bank as a Main Bank.}

Despite the importance of their role as secondary lenders to firms belonging to the groups of other banks, the long-term credit banks, especially the largest and most prestigious of them, the Industrial Bank of Japan (IBJ), have maintained a large number of relationships with corporations in which there is little doubt that they are the main bank. In fact, a subset of these firms are so heavily influenced by IBJ loans and personnel appointments that a minor keiretsu group is often viewed to have grown up around IBJ (Exhibit 10).

In addition, IBJ has very close relationships with a number of the largest vertical groups which are either independent or only loosely affiliated with the six bank groups: Nippon Steel, Nissan Motor, Hitachi. ${ }^{\text {ss }}$ IBJ has consistently been the largest single lender to the apex of these vertical groups, and as will be discussed later, to an exceptionally large proportion of the listed firms within those groups.

4.1 Bank Loans ( $\delta$ ). In Chapter 1 of this volume, a number of aspects of the relations

${ }^{\text {s5 }}$ The three companies which head these groups are the fourth, fifth, and sixth largest shareholders of IBJ (Meiji, Nippon, and Dai-Ichi Life Insurance are the lead shareholders). These ties pre-date World War II, when IBJ developed close relationships with the new zaibatsu (shinko zaibatsu) such as Nissan (the nuclei of which were Nissan Motor and Hitachi), Nippon Chisso, and Mori. (IBJ: 50) The relationship with Japan Steel goes far back as well: IBJ headed syndicates for distributing and absorbing issues of Japan Iron and Steel Company, which was established in 1934 by the consolidation of the government's Yawata works and six private firms. (Cohen: 17,26) The firm was broken up into two separate entities during the occupation, but reestablished with the Yawata/Fuji merger of 1968. (Hadley: 297-298) 
between a firm and its main bank were introduced. Table 5 compares the three long-term credit banks with the city banks across across three of these aspects for the purposes of roughly comparing the relative number of "main bank" relationships among the banks at two widely separated points in time: 1967 and 1990 . One characteristic of these data is that there exists a clear differentiation among the long-term credit banks in the number of lead lending relationships with listed companies. ${ }^{56}$ IBJ in 1967 was the lead lender to 70 companies listed on the first section of the Tokyo Stock Exchange, which was a number comparable with the average of 71 for the six major keiretsu groups. Meanwhile, LTCB and NCB lagged far behind the group banks with 20 and 4 companies, respectively, to which they were the lead lenders, numbers more similar in scale to the second tier of city banks.

Although the distinction between the long-term credit banks in the number of lead lending relationships remained evident in 1990 , the number of lead lending relationships relative to other banks had slipped for IBJ, the number of which was lower than five of the six major groups (though still far above any of the other city banks). The numbers for LTCB and NCB remained comparable to those of the second tier of city banks, though as with IBJ, somewhat lower on a relative scale than 23 years previously..$^{57}$

\footnotetext{
${ }^{56}$ The lead lender is determined as explained in footnote 39. The above-mentioned differentiation has extended to the second section companies as well. For instance, while IBJ was the lead lender to 41 companies listed on the second section of the Tokyo Stock Exchange in 1967 (keiretsu group average: 43 firms), the LTCB was the lead lender to 14 firms and NCB to 12. There has also been a consistent difference in the size of the bank firms affiliated with each longterm credit bank, with net sale approximately 4 times as large on average for IBJ-affiliated firms. (Keiretsu no Kenkyu, 1991)

${ }^{57}$ The decline in relative position could be interpreted as suggesting that a number of companies to which the long-term credit banks were leading lenders in 1967 had returned to the keiretsu group fold by 1990 . However, a reexamination of the data used in Horiuchi, Packer, and Fukuda (1988) of a sample of companies continuously listed from 1963 to 1987 has unearthed no such general trend. A more likely explanation is that there is today a greater proportion of listed firms from industries in which the long-term credit banks have a relatively low representation, e.g.,
} 
4.2 The Supply of Management Information and Resources (e). In the area of transfers of employees to director positions at related companies, a commonly used indicator of close firmbank relationships in Japan, IBJ was and has remained a peer of the six group banks, while the numbers for LTCB and NCB are at a lower level comparable with the second tier of city banks. In contrast to the lead lender indicator, the relative position of this indicator has not changed greatly for IBJ, while it has grown greatly for LTCB.

Not all director positions are the same. In general, managerial authority in Japanese companies in concentrated in either the president (hacho) or chairman ( $\underline{\text { kaicho }}$ ) position. In terms of placement to these positions, IBJ does much better than its city bank counterparts, with 17 companies compared to 10 for the nearest city bank. ${ }^{58}$ Similarly, LTCB placements significantly exceed those of the second tier of city banks.

4.3 Shareholding(B). As is evident in Table 5, in terms of share ownership looked at by banks in isolation, IBJ is again a peer of the six group banks, being a principal financial institution shareholder in a number of cases comparable to those of the major city banks. ${ }^{59}$ On the other hand, LTCB and NCB lag in stock ownership relative to the second tier of city banks.

services.

so This suggests that IBJ has had an exceptional pool of employees from which to supply managerial resources, and lends some credibility to one of IBJ's many nicknames, "The PresidentExport Bank" (Shacho Yushutsu Ginko). (Nihon Jitsugyo Shuppansha, 52). IBJ's role in mediating mergers (discussed below) may also be responsible. In the case of Japan Line, an IBJ man was appointed president in part to smooth over factional disputes resulting from a 1964 merger.

${ }^{59}$ However, as the IBJ group of closely affiliated companies is not only far smaller but also does not include any of two classes of major shareholders in Japan, insurance companies and trust banks, there can be no significant comparison with the aggregate cross-shareholdingproportions of the keiretsu groups. One recent estimate of the percent of group company shares held by group firms ranges from 25\% for the Mitsubishi group to $11 \%$ for the Sanwa group. (Keiretsu no kenkyu, 1991) 
In contrast to its roles of principal lender and supplier of director personnel to related companies, the emergence of IBJ as a major bank shareholder in the Japanese economy is a relatively recent phenomenon. In the early 60 s, despite having a large number of customers, IBJ used most of its funds on lending and invested relatively little in the equity of many of its clients. Out of the 70 first section firms for which it was the lead lender in 1967, it was not a top ten shareholder for nearly one-quarter; further, it held less than $2 \%$ in another fifth of the cases. (Keiretsu no Kenkyu, 1968)

However, the shareholding role of the long-term credit banks has increased substantially to the point where IBJ overall share ownership now exceeds that of any of the city banks. By 1990, IBJ owned an average of $4.3 \%$ of the first-section listed companies to which it was a top lender. By comparison with 1967 , for only $4 \%$ of the companies to which it is the lead lender did it not own stock, and only in another $6 \%$ of the cases did it own less than $2 \%$ of the company's shares.

In common with the other city banks, large shareholding stakes are not limited to companies to which it is the lead lender, but extend across a wide range of companies many of which are owned in larger proportion by other banks. (Table 5)

4.4 Payment Settlement Accounts and Bond-Issue Related Services (a,7). A critical feature of Japan's long-term credit bank law is that while it prohibits the practice of consumer banking, it does not prohibit any of the standard banking practices which are essential to the establishment of close firm-bank ties in Japan, and constitute the different dimensions of the main bank relationship introduced in Chapter 1. We have already discussed the provision of loans, shareholding, and the supply of management information and resources. But allowed activities also include the taking of corporate deposits to facilitate payment settlement (a), bond-issue related services ( $)$, the two remaining aspects of the paradigmatic main bank relationship. 
With regards to payment settlement (a), when required to do so, long-term credit banks are fully capable of providing the services of their city bank counterparts. Since long-term credit banks are limited to accepting deposits from corporate clients and government institutions, one rough indication of their activity in this area is the amount of deposits held: in 1960, deposits amounted to $17.7 \%$ of outstanding loans by IBJ; by 1978 , that percentage had increased to $33.3 \%$. (IBJ, Supplementary Volume, 26-31). Another more recent and precise indication of their activity in this area can be found by looking at the identity of paying bank of bills cleared in clearinghouse data. In 1989, about 127 trillion yen of bills were presented at the Tokyo Clearinghouse to be drawn on IBJ accounts, and 60 and 47 trillion yen of bills to be drawn on LTCB and NCB accounts, respectively. This compared with an average of 232 trillion for the six major city banks and 104 trillion for the other city banks. (Zenginko Kyokai, 1990) ${ }^{60}$

Bond issue related services ( 9 ) is another aspect in which long-term credit banks are equally capable of solidifying the main bank relationship. Documentation concerning this point is provided in another paper of this volume (Hamao and Campbell). With regards to the guarantees of straight and warrant attached bonds, as well trustee administration for straight, convertible, and warrant bonds, IBJ, just like the six major city banks, is far more likely to be involved if it is the lead lender to the company.

4.5 The Importance of Ties with Vertical Groups. As mentioned above, IBJ has a number of close relationships with the heads of large vertical groups which are either independent or only

${ }^{60}$ Whether the somewhat lesser importance of long-term credit banks along this dimension compared to others reflects the larger sampie (bills of companies regardless of listing status), the fact that their clients may rely less on inter-firm transactions, or in fact, a weaker main bank relationship along this dimension cannot be answered without firm-specific data. What the clearinghouse data do tell us, however, is that the long-term credit banks are very active as paying and collection banks in the nationwide promissory note markets. 
loosely affiliated with one of the six bank groups. Of course, there are many other vertical groups which lie firmly within the bank group axes as well (e.g., the Mitsubishi Electric Group, the Sumitomo Metal Industries group). Undoubtedly, firms of a vertical group whose head has a strong bank group affiliation will be more likely to have a bank from that group as its principal lender. But what extent does membership in certain vertical groups affect the probability of having IBJ as the main bank?

In the interest of abstracting from the biases of industry specialization and size, for each company listed on the First or Second Section of the Tokyo Stock Exchange to which IBJ was identified as the principal lender in 1990 , a company from the same industry ${ }^{61}$ was chosen which was closest to the original company in terms of net sales, but did not have a long-term credit bank as its lead lender. If no companion could be found within a factor of 2 , the original (IBJ-affiliated) company was dropped from the sample..$^{62}$

Characteristics of the resulting sample are given in Table 6. Predictably, the large majority of the non-IBJ-affiliatedfirms have group financial institutions as their lead lender. While there do not appear to be significant differences between IBJ and non-IBJ affiliated firms in terms of financial statistics such as the debt-equity ratio, the ratio of loans to debt, or the ratio of bonds issued to long-term liabilities, IBJ firms do have a significantly higher ratio of long-term loans to all loans. Convergence of term composition in lending to listed firms by city and long-term credit banks does not appear to have occurred.

\footnotetext{
${ }^{61}$ Industry classifications were those in the Japan Company Handbook, 1991 (1): 2-3.

[Predictably, company pairs were the most difficult to construct in the electric power industry, where 7 firms to which IBJ was the lead private lender were dropped from the sample.
} 
The lending shares are also of interest. While the average of IBJ loan shares significantly exceeds that of the individual group banks by more than $6 \%$, differences in the share figures are insignificantly different from zero when we compare them to the lending of all financial institutions in the relevant bank group. The data related to JDB lending suggest that IBJ-affiliated firms have neither an advantage nor disadvantage when it comes to receiving JDB loans. After industry and size factors are controlled for, financing from JDB is not greater than average for IBJ-affiliated firms, particularly when compared to group bank affiliated firms. ${ }^{63}$

The final two columns indicate the importance of ties with vertical groups. In the first of these, we list the number of companies which either have $20 \%$ or more of their shares owned by another listed company, or are listed as belonging to the vertical group of another listed firm in Toyo Keizai's Nihon no Kigyo Grupu, $1991 .^{\text {(4 }}$ In the final column, we list the number of those vertical-group affiliated firms for which the group head has IBJ as the lead lender. Unlike the number of all vertical group affiliates, which differs little for IBJ and non-IBJ firms, the number of firms whose group head also had IBJ as its lead lender is significantly larger - by two to three times - for the IBJ companies than for the six bank keiretsu. Thus, the strong linkage between vertical group membership and the identity of the main bank extends to IBJ.

\subsection{Aspects of the IBJ Record for Borrowing Firms in Financial Distress. Much of the} main bank literature relates to the role that main banks take when a firm falls into financial

\footnotetext{
${ }^{63}$ However, firms that are affiliated with a smaller city bank are less likely to have JDB funding, and firms that are independent are more likely to have JDB funding. The latter result is consistent with those of a recent paper on the impact of JDB loans, which found that the impact of a JDB loan on borrowing and investment is greater if the firm does not have a main bank. (Horiuchi and Sui, 1993)

"In general, the two categories are the same, though Kigyo Grupu does make a few important omissions as well include a few firms which hold less than $20 \%$.
} 
distress. In particular, a chapter to follow in this volume addresses this issue in great depth.

(Sheard) In the following, we provide some further evidence that the Industrial Bank of Japan has acted as a main bank for a number of important cases, as well as explore certain aspects of the IBJ-led resolution of financial distress that reflect in particular its status as a bank neutral of keiretsu affiliation and with special government connections.

\subsubsection{Active Managerial Intervention. As early in the post-war era as May 1953,} Nippon Yakin Kogyo, a specialty steel manufacturer, averted bankruptcy through the support of Bank of Japan and a syndicate of private banks led by IBJ. In what became a case of considerable controversy, IBJ forced the president and five other directors to sign a contract agreeing to their unanimous resignation and demanded not only that an IBJ employee be made vice-president, but also that their hand-picked successor - a president of a competing company in the same industry take over the company as president. ${ }^{65}$ More than 20 years later, with an IBJ man as president, IBJ led a syndicate of banks in providing further financial assistance to this same company, mandating internal cost-cutting measures as well as organizing tie-ups and assistance from Showa Denko and Nippon Steel. (Sheard, 1989: 415,419)

Another reknowned case was that of Nittoku Metal Industry, a manufacturer of small bulldozers and other industrial machinery, which was listed on the first section of the Tokyo Stock Exchange, with around 1600 employees. In November 1964, its parent company Nihon Special Steel, went bankrupt after its lead banks, Mitsubishi and Daiichi, had rejected IBJ requests to

\footnotetext{
${ }^{6}$ Later in 1953, the Fair Trade Commission heard a suit from a disgruntled Nippon Yakin Kogyo director, who charged that the management shakeup consisted a breach of the new AntiMonopoly law. The case further gained notoriety when the Asahi newspaper reported charges of "financial intimidation" by this same director. Although the FTC did not follow up on the case, it did issue a warning to IBJ that certain actions taken had been inappropriate, and minor adjustments were made in the makeup of the board. (IBJ: 216-218).
} 
rescue the company. By contrast, after sending over a team of four employees to investigate its condition, IBJ decided to rescue the subsidiary to which it was the lead lender, supplying the necessary amounts of emergency financing, and convincing other banks to refrain from forcing default. By the next year, after shopping around, ${ }^{\star 6} \mathrm{IBJ}$ had located a willing partner for a joint venture in Sumitomo Machinery, which put the company back on its feet. (IBJ, 532)

A more recent case of active intervention is that of machine tool maker Ikegai Tekko in 1984, where under a president sent in by IBJ, rationalization measures including asset disposal took place, and a joint venture mediated with another firm in the industry, Tsugami. (Sheard, 1989: 420) Both this and previous case suggest that an important supplement to IBJ managerial intervention has been the search for industrial partners to assist in the rehabilitation of the company, a feature to be examined in greater detail below.

\subsubsection{The Search for Merger or Joint Venture Partners. Studies of the keiretsu} groups often emphasize how intra-group coordination facilitates restructuring and mergers within the group (Gerlach, 1992). The main bank leadership role in this regard can be seen as substituting for an external takeover market (Sheard, 1989) While IBJ's active intervention is consistent with this interpretation, all three of the cases described above illustrate an additional element to IBJ's role: the ability to find merger or joint venture partners and negotiate with the banks and companies of other groups. ${ }^{67}$

"Other candidates which had been approached included Komatsu and Hitachi. For a dramatized account of the rescue of Nittoku Metal Industry, see Takasugi, II, 69-107.

${ }^{67}$ Showa Denko's main bank was Fuji, Sumitomo Machinery's was Sumitomo, and Tsugami's was Mitsui. 
IBJ's position of group neutrality in the mediation of mergers has given it an especially prominent role in periods of government encouraged industry rationalization. ${ }^{68}$ In the automobile industry in the mid-60s, IBJ played an important mediator role in the merger of Nissan and Prince, negotiating with Sumitomo Bank, the main bank of Prince. (IBJ: 679-681) In the drastic rationalization of the shipping industry in 1964, IBJ acitvely mediated two of the six mergers, one of which involved a firm listed in the Mitsubishi group, and another of which involved close cooperation with the Daiichi Bank. ${ }^{69}$ (Keiretsu no Kenkyu, 1961; IBJ:470-478)

Of course, the range of IBJ main bank clients is large enough that there often occur mergers and tieups of companies both of which have IBJ as their main bank. Shortly after the Yakin Kogyo incident in 1955, IBJ assisted another special steel client, Daido Special Steel in the midst of a credit crunch and mediated a merger with Shin Riken. (IBJ: 203-204) Though not an outright merger, a significant capital alliance which IBJ later put together after the Nissan/Prince merger in the same industry was between Nissan and another company for which IBJ acted as the main bank, Fuji Heavy Industries. (IBJ, 684) In the early seventies, IBJ helped to mediate a merger between two of the largest companies in the paper and pulp business - Sanyo and Kokusaku pulp. (IBJ, 933)

IBJ also played a major role in the single most significant industrial merger of the post-war era: that of Yawata and Fuji Steel to form New Japan Steel in 1969. Working in cooperation with MITI, they not only acted as an intermediator in the corporate negotiations, but also proposed the necessary spinoffs and technological agreements to satisfy the FTC, including a sale of a

\footnotetext{
${ }^{6}$ By contrast, major merger cases involving different companies of the six bank keiretsu are almost unheard of. In a study of 63 major merger cases in Japan between 1953 and 1973, one researcher has found that only one occurred between companies of different kigyo shudan. (Iwasaki: 503)

${ }^{60}$ The first of the merged firms became Japan Line, the IBJ main bank client discussed below.
} 
segment of the business to NKK, a firm to which they were a major, though not lead, lender. Throughout the highly public debate which surrounded the merger of the two largest firms in the Japanese steel industry, IBJ made a strong case for its benefits. (688-705)

4.6.3 The Securities Industry Crisis. IBJ's special relationship with the government has also meant that they are often called on to represent the private financial sector in industry crises of national significance. IBJ's central role in the Japanese economy was no more evident than during the financial crisis of the securities industry in $1964-1965$, which surfaced dramatically in the insolvency of Yamaichi Securities. IBJ men were brought in as presidents for all of the Big Four securities companies except Nomura. When Yamaichi's situation worsened, IBJ negotiated a rehabilitation plan which involved employee layoffs as well as the suspension and reduction of interest payments together with the two other lead banks of Mitsubishi and Fuji. When it became apparent that investor confidence was beyond repair without government assistance, IBJ successfully lobbied for special relief financing from the Bank of Japan. A smaller securities firm Oi (now Wako) was saved in similar fashion, and IBJ played a further intemediary role in the merger of three troubled securities firms to form Shin Nihon Shoken. ${ }^{n}$

4.6.4 The Case of Japan Line. The record of IBJ intervention of course is far longer than the small number of major cases briefly discussed above. Neither have large and important cases been limited to the high-growth era, as the very recent case of Japan Line to be discussed in a later chapter of this volume illustrates. (Sheard, appendix) A few aspects of this case are worthy of additional mention here. ${ }^{n}$

${ }^{70} \mathrm{~A}$ dramatized account of IBJ's role in the securities industry crisis is to be found in Takasugi (IV, 262-298); IBJ's official account is to be found in its history (780-783).

${ }^{71}$ Source articles are to be found Japan Economic Journal, 12 Dec. 1986, 17 June, 1989, Nikkei News Bulletin (on Nikkei telecom) 11 May, 1989. See also citations in Sheard, appendix. 
First, the characteristic IBJ search across groups for a merger partner for Japan Line was part of the end game. The IBJ-selected merger partner was Yamashita-Shin Nihon, for which IBJ was the second largest lender and bank shareholder after Sanwa Bank. A merger followed intense negotiations with Sanwa Bank, where IBJ agreed to further writeoffs of its outstanding loans as a condition of the merger.

Secondly, even though JDB consistently had more loans on an absolute basis than IBJ, there appears to have been little question that IBJ was the bank primarily responsible for managing the crisis, and all indications are that IBJ took the leadership role and bore a greatly disproportionateshare of the losses. Outstanding JDB loans may have lent a political aspect to the case which IBJ probably was able to take advantage of. Both during the many years of restructuring which preceded the merger, and after the merger, IBJ lobbied hard with the Ministry of Finance, including personal meetings with then Finance Minister Miyazawa, to obtain permission for most of the debt-writeoffs to be taken as deductions from taxable income. 


\section{Conclusion.}

In this paper on the role of the long-term credit banks, we have deliberately focused on its positive aspects. Both in terms of providing an active and knowledgeable participant in the syndication of credits, and in terms of providing a counterbalance to inward-looking aspects of the city bank groups, the long-term credit banks have been an important part of the main bank system. Acting at times in the capacity of independent development banks and and at times in the capacity of main banks, the long-term credit banks have been heavily involved in both the financing of growing sectors and the restructuring of troubled ones. In particular, as befits its size and history, the role of IBJ has been central.

Nonetheless, it should be kept in mind that a major reason the long-term credit banks have maintained a prominent position in the Japanese financial system - for all their ability in creditanalysis and the provision of long-term funds - has been the successful maintenance of a strong demand for their financial debentures. Part of this success has been the result of law and public policy, and another part has been due to the marketing efforts of the long-term credit banks themselves. One of the important post-war achievements of the long-term credit banks was the cultivation of new classes of purchasers once government bonds came on the scene.

For the past 40 years, financial policymakers in Japan have chosen not to present the longterm credit banks with the additional challenges that an unregulated domestic bond market would undoubtedly bring about. Any historical assessment of the role of the long-term credit banks must place the very real contributions made to Japanese economic growth alongside the costs of a corporate bond market which as of the early 90 s was still underdeveloped. But given the choice of a bank-led financing system, which also encourages very close bank-company relations, it is this author's opinion that the role of the long-term credit banks has been indispensable. 


\section{REFERENCES}

Adams, T.F.M., Iwao Hoshii. 1972. A Financial History of the New Japan. Tokyo: Kodansha.

Aoki, Masahiko and Paul Sheard. 1992. The Role of the Main Bank in the Corporate Governance Structure in Japan." Mimeo, Stanford University.

Ballon, Robert J., Iwao Tomita. 1988. The Financial Behavior of Japanese Corporations. New York: Kodansha.

The Bank of Japan, Institute for Monetary and Economic Studies. 1986. Wagi Kuni no Kinyu Seido. Tokyo.

Cohen, Jerome B. 1949. Japan's Economy in War and Reconstruction. Minneapolis: University of Minnesota Press.

Corbett, Jenny. "International Perspective on Financing: Evidence from Japan." Oxford Review of Economic Policy. Vol.3 (4).

Diamond, Douglas. 1990. "Debt Maturity Structure and Liquidity Risk," Quarterly Journal of Economics. 106 (3), p 709-737.

Diamond, Douglas. 1991. "Seniority and Maturity Structure of Bank Loans and Publicly Traded Debt." Mimeo, Chicago Graduate School of Business.

Doi, Satoshi. 1990. "The Bank Debenture Market." In Frank Fabozzi, ed. The Japanese Bond Markets: An Overview and Analysis. Chicago: Probus Publishing Company.

Feldman, Robert, Yuzo Harada, Eisuke Sakakibara. March 12, 1982. The Japanese Financial System in Comparative Perspective. Joint Economic Committee, Congress of the United States. Washington.

Flannery, Mark J. 1986. "Asymmetric Information and Risky Debt Maturity Choice," Journal of Finance $v 41$, p 19-38.

Fukuzawa, Toshihiko. 1987. "Deregulation of Financial Market Segmentation (Part I: The Reforms which are needed in Long- and Short-Term Segmentation)" Fair Fact Series: Japan's Financial Markets v 13.

Gerlach, Michael. 1992. Keiretsu: A Primer. New York: Japan Society.

Gorton, Gary, and G. Pennachi. December 1990. "Banking and Loan Sales: Marketing NonMarketable Assets." Working Paper, National Bureau of Economic Research. Cambridge, MA.

Hadley, Eleanor. 1970. Antitrust in Japan. Princeton: Princeton University Press. 
Hamada, Koichi, Akiyoshi Horiuchi. 1987. "The Political Economy of the Financial Market." In Yamamura, Kozo and Yasukichi Yasuba, ed. The Political Economy of Japan: The Domestic Transformation. Stanford: Stanford University Press.

Hazama, Otohiko. 1975. Nihon no Ruishinban: Nakayama Sohei. Tokyo: Gekkanpensha.

Higano, Mikinari. 1986. Kinyu Kikan no Shinsa Noryoku. Tokyo: Tokyo University Press.

Horiuchi, Akiyoshi, Frank Packer and Shin'ichi Fukuda. 1988. "What Role Has the 'Main Bank'Played in Japan?" Journal of Japanese and International Economies $v 2$ (2), p 159-180.

Horiuchi, Akiyoshi and Qing-yuan Sui. "Influence of Japan Development Banks Loans on Corporate Investment Behavior." Forthcoming, Journal of Japanese and International Economies.

Horiuchi, Toshihiro. 1988. Mein Banku Kyoso to Kashidashi Shijo. Tokyo: Toyo Keizai.

Horiuchi, Toshihiro. April 1990. The Adjustment and Restructuring of Japan's Syntehtic Fiber Industry - Real and Financial Interdependence." JCER-RAND Conference paper.

Hoshi, Takeo. March 1993. "Evolution of the Main Bank System in Japan." Mimeo, University of California, San Diego.

Hoshi, Takeo, Anil Kashyap, and David Scharfstein. 1990. "The Role of Banks in Reducing the Costs of Financial Distress in Japan." Journal of Financial Economics v 27 p 67-88.

Hoshi, Takeo, Takatoshi Ito. February 1991. "Measuring Coherence of Japanese Enterprise Groups." Paper presented at TCER Finance Conference.

The Industrial Bank of Japan. 1957. Nihon Kogyo Ginko: Goju Nenshi. Tokyo.

The Industrial Bank of Japan. 1982. Nihon Kogyo Ginko: Shichijugo Nenshi. Tokyo.

Itoh, Yoshiaki. March 15, 1993. "Cracking Down on Tax Evasion," The Nikkei Weekly.

Iwasaki, Akira. 1988. "Mergers and Reorganizations." in Komiya, Ryutaro, Okuno, Masahiro, and Kotaro Suzumura, editors, Industrial Policy of Japan. New York: Academic Press.

Japan Development Bank. 1976. Nihon Kaihatsu Ginko: Nijugo Nen Shi. Tokyo.

Japan Development Bank, Japan Economic Research Institute. January 1993. Policy Based Finance: The Experience of Postwar Japan. Tokyo.

Kim, Sun Bae. 1991. "Lenders cum Shareholders: How Japanese Banks Financed Rapid Growth." $\mathrm{Ph} . \mathrm{D}$ dissertation, University of Toronto. 
Kinyu Seido Chosakai. 1987. Senmon Kinuu Kikan Seido no Arikatani Tsuite. Senmon Iinkai Hokoku, Tokyo.

Ministry of Finance. 1976. Showa Zaisei-shi: Shusen kara Kowa made. Vol. 12. Tokyo: Toyo Keizai Shinposha.

Ministry of Finance. 1983. Showa Zaisei-shi: Shusen kara Kowa made. Vol. 13. Tokyo: Toyo Keizai Shinposha.

Osono, Tomokazu. 1991. Kigyo Keiretsu to Gyokai Chizu. Tokyo: Nihon Jitsugyo Shuppansha.

Packer, Frank, Marc Ryser. 1992. "The Governance of Failure: An Anatomy of Corporate Bankruptcy in Japan." Working Paper No. 62, Center on Japanese Economy and Business, Graduate School of Business, Columbia University. New York.

Patrick Hugh. 1967. "Japan: 1868-1914" in Banking and the Early Stages of Industrialization. R. Cameron et al. New York: Oxford University Press.

Patrick Hugh. 1972. "Finance, Capital Markets and Economic Growth in Japan," In Arnold Sametz editor, Financial Development and Economic Growth. New York: New York University Press.

Pressnel, L.S., ed. 1973. The Bank of Japan Research Department. Money and Banking in Japan. New York.

Ramseyer, Mark. 1991. "Legal Rules in Repeated Deals: Banking in the Shadow of Defection in Japan." Journal of Legal Studies v 20, p 91-117.

Schleifer, Andrei, Robert Vishny. 1991. "Asset Sales and Debt Capacity." Working Paper No. 3618, National Bureau of Economic Research. Cambridge, MA.

Sheard, Paul. 1989. "The Main Bank System and Corporate Monitoring and Control in Japan." Journal of Economic Behavior and Organization v 11 p 399-422.

Sheard, Paul. November 1991. "Delegated Monitoring Among Delegated Monitors: Principal-Agent Aspects of the Japanese Main Bank System." Center for Economic Policy Research Publication No. 274. Stanford, Callifornia.

Shimura, Kiichi. 1978. Gendai Nihon Koshasairon. Tokyo: Tokyo University Press.

Shimura, Kiichi. 1980. Nihon Koshasai Shijoshi. Tokyo: Tokyo University Press.

Suzuki, Sadahiko, Richard Wright. 1985. "Financial Structure and Bankruptcy Risk in Japan." Journal of International Business Studies v 16 p 97-110.

Suzuki, Yoshio, ed. 1987. The Japanese Financial System. Oxford: Clarendon Press. 
Tachibanaki, Toshiaki, and Atsuhiro Taki. 1991. "Shareholding and Lending Activity of Financial Institutions in Japan," 9 Monetary and Economic Studies, v 9 p 23-60. Institute for Monetary and Economic Studies, Bank of Japan.

Takasugi, Ryo. 1987. Shosetsu: Nihon Kogyo Ginko. 5 volumes. Tokyo: Kodansha.

Takenaka, Ichiro. 1968. Choki Kinyu Kiko no Bunseki. Tokyo: Toyo Keizai.

Tanikawa, Hiroshi, and David Allan, Mary Hiscock, and Derek Roebuck. 1973. Credit and Security in Japan: The Legal Problems of Development Finance. New York: Crane, Russak \& Company.

Teranishi, Juro. 1982. Nihon no Keizai Hatten to Kinyu. Tokyo: Iwaba Shoten.

Yasuda, Ayako. 1993. The Performance and Roles of Japanese Development Banks. Seniors Honors Thesis, Department of Economics, Stanford University.

Zenginko Kyokai Rengokai. 1990. Tegata Kokan Tokei Nenpo. Tokyo: Tokyo Ginko Kyokai. 


\section{TABLE 1: IMPORTANT DISTINCTIONSOF THE LONG-TERM CREDIT BANK LAW}

\section{Long-Term Credit Bank Law (1952)}

Purpose

Definition

Long and

Short-term

Finance

Required

Prudential

Measures

Limitation on Loans to Single Costomers

The Acceptance of Deposits and Instalment Savings
Issuance of Debentures
"... to streamline long-term finance, to ensure the proper supervision of long-term credit bank ... and at the same time contribute to the maintenance of the financial system by means of a functional differentiation of the banking business." (Art. 1)

"... any (juridicial) person which intends to engage as its principal business in the lending of equipment capital or long-term working capital through the issuance of debentures instead of through the acceptance of deposits." (Art. 4.1)

"... may make loans, discount bills, guarantee obligations, or accept bills with regard to equipment capital or long-term working capital." (Art. 6.1.1)

"... may make loans, secured by real estate, of long-term capital (more than 6 months) other than equipment capital and long-term working capital." (Art. 6.2)

"... may make loans, discount bills, guarantee obligations or accept bills with regard to short-term capital (less than 6 months) within the limits of an amount equal to the total of accepted and other money of a similar nature." (Art. 6.2)

"... in order to ensure the preservation and collection of its claims ... with regards to long-term capital, ... shall give special consideration to such means as requiring sound collateral or redemption of the loans on an instalment basis." (Art. 7)

$30 \%$ capital and surplus funds. (SupplementaryProvisions, Art. 6)

"Acceptance of deposits or instalment savings limited to acceptance of those from the State, local public bodies, borrowers, companies for which the bank acts as trustee in the issuance of corporate bonds, and other customers." (Art. 6, No. 3)

Up to 30 times capital and reserves. (Art. 8)

\section{Banking Law (1981)}

"... to aim at the maintenance of credit, and smoothness of financing together with ensuring protection of depositors, to ensure healthy and proper management of the banking business, and contribute to the healthy development of the national economy." (Art. 1)

"an institution which is engaged in ...

1) Receiving of deposits or installment savings together with lending of funds or discounting bills or notes; 2 ) Carrying on of exchange transactions." (Art. 22)

No distinction made.

No similar provisions.

$20 \%$ of capital and surplus funds. (SupplementaryProvisions, Art. 4)

No limitation.

Not allowed. 
TABLE 2: ADVANTAGES OF FINANCIAL DEBENTURES

Ordinary Corporate

Debentures

Amount of Issuance

Ease of Issuance and Distribution for city banks.
Liquidity Features
Ceiling for bondissuance is lower of capital and reserves, or net asset value for corporations, up to 2 times capital and reserves

Subscription may not begin until after application submitted to MoF and approval obtained.

Have to abandon financing when there is a subscription shortage.

Most are required to be issued on a secured basis.

Public issues issued through direct subsciption, whereby issuing amount and terms are publically announced, and investors submit issuer-prepared application forms to designated securites firms, and are allocated a share upon issuance.

Direct subscription must take place through securities firm.

Minimum unit of purchase is $¥ 100,000$.

Purchaser registered.

-..-

Tax

Treatment
Withholding tax on interest of $15-20 \%$ from 1967-1978. Current withholding tax is $20 \%$.
Financial

Debentures

Ceiling is $\mathbf{3 0}$ times capital and reserves for long-term credit banks. (Art. 8)

Must only report amount and terms of issue.

Allowed to reduce the amount of issue to the amount subscribed. (Gengaku hakko)

Security not required.

Investors can buy and obtain certificates at any time after one month prior to issuance. Subscriptions and application forms unnecessary. (Uridashi)

Bank can sell their own debentures.

Minimum unit of purchase is $¥ 10,000$.

Bearer bonds.

Accepted as collateral for borrowings from the Bank of Japan during highgrowth era.

Used as target for BoJ market operations during high growth era.

Were commonly used as collateral to to raise money in the call money money market in the high growth era. Securities companies were allowed until 1965 to post customers' debentures as collateral. (Unyo azukari)

$5 \%$ withholding tax on discount bonds from 1967-1978. Current withholding tax of $18 \%$.

Discount bonds set a few basis points above the comparable one-year deposit rate (from 1967). 
Table 3

The Share in Outstanding Loans for Plant and Equipment Investment in Selected Industries by Bank Category (percent)

1956

1966

Long-Term
Credit
Banks

Machinery

Chemicals

Textlles

Mining

steel and Iron

Shipping

Electric Power

All Loans for P\&E Investment
64.78 $14.58 \quad 6.88$

$56.28 \quad 14.98 \quad 10.78$

$47.88 \quad 14.98 \quad 21.28$

$42.18 \quad 49.68 \quad 1.48$

$63.78 \quad 22.58 \quad 4.28$

$22.58 \quad 47.68 \quad 24.78$

$29.28 \quad 46.38 \quad 12.28$

$37.58 \quad 33.18 \quad 16.88$
1974

\begin{tabular}{rrr}
$\begin{array}{l}\text { Long-Term } \\
\text { Credit } \\
\text { Banks }\end{array}$ & \multicolumn{1}{c}{ JDB } & \multicolumn{1}{c}{$\begin{array}{l}\text { City } \\
\text { Banks }\end{array}$} \\
42.98 & 5.98 & 5.08 \\
41.58 & 10.38 & 14.48 \\
46.78 & 5.68 & 7.68 \\
20.08 & 71.48 & 2.08 \\
43.98 & 2.68 & 9.58 \\
3.58 & 70.88 & 9.88 \\
28.18 & 44.78 & 6.18 \\
36.18 & 17.48 & 15.28
\end{tabular}

\begin{tabular}{|c|c|c|}
\hline $\begin{array}{l}\text { Long-Te } \\
\text { Credit } \\
\text { Banks }\end{array}$ & $\begin{array}{l}\mathrm{rm} \\
\mathrm{JDB}\end{array}$ & $\begin{array}{l}\text { ity } \\
\text { anks }\end{array}$ \\
\hline 36.78 & 5.58 & 18.48 \\
\hline 38.08 & 7.38 & 18.68 \\
\hline 35.18 & 7.18 & 18.18 \\
\hline 26.78 & 34.58 & 12.98 \\
\hline 39.78 & 3.48 & 15.88 \\
\hline 17.78 & 59.78 & 12.98 \\
\hline 32.18 & 28.28 & 11.18 \\
\hline 9. & 11.38 & 30 \\
\hline
\end{tabular}

1988

\begin{tabular}{|c|c|c|}
\hline $\begin{array}{l}\text { Long-Ter } \\
\text { Credit } \\
\text { Banks }\end{array}$ & $\begin{array}{l}\mathrm{rm} \\
\mathrm{JDB}\end{array}$ & $\begin{array}{l}\text { City } \\
\text { Banks }\end{array}$ \\
\hline 12.08 & 5.68 & 28.68 \\
\hline 26.28 & 14.18 & 26.78 \\
\hline 7.78 & 3.18 & 25.88 \\
\hline 12.18 & 8.58 & 13.18 \\
\hline 28.68 & 10.58 & 15.28 \\
\hline 9.88 & 39.28 & 14.58 \\
\hline 25.68 & 35.38 & 10.48 \\
\hline 8 & 6.08 & 32.9 \\
\hline
\end{tabular}

Source: IBJ 75 Year History for years 1956, 1968, 1974 (pp. 208, 211,540,946), The Bank of Japan Economic.Statistics Annual, (1989, Table on Job lóns) and Nikkei Telecom Data Service for 1988 .

Note: The category of machinery includes general industrial machinery electric machine tools, transportation machinery (including automobiles and ships), and precision machinery. rotals do not add up tó 1008 since trust accounts comprise the remainder. 
Table 4: The Industry Breakdown of Cooperative Pinancing Among the Long-term Credit Banks and JDB: Companies Listed on the Tokyo Stock Exchange, 1967.
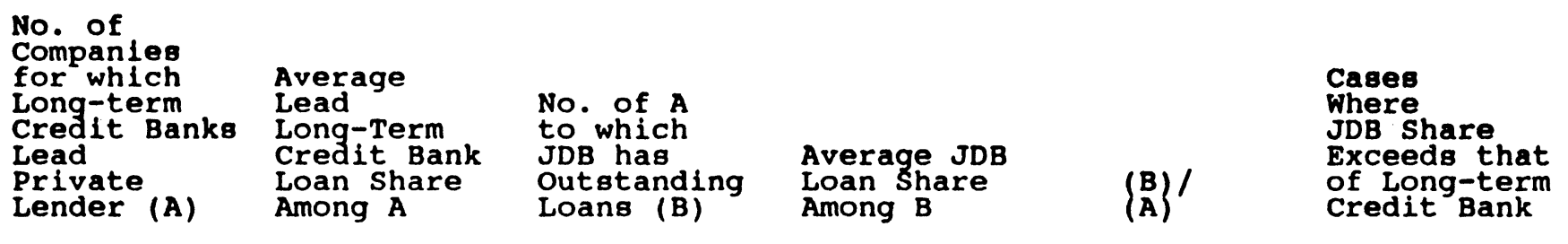

Mining

7

218

5

288

718

3

steel

25

338

12

58

488

118

498

88

488

148

508

538

788

458

1008

488

218

1

Source: Table constructed from data of Kelzal Choga Kai Reiretsu no Renkyu (1968), First Section Listed Company Volume, pp. 230-278; Second section Listed Company volume, pp. 31-105. 
Table 5: Main Bank Indicators: The Long-Term Credit Banks Compared with Other Banks

(18t section Tokyo)

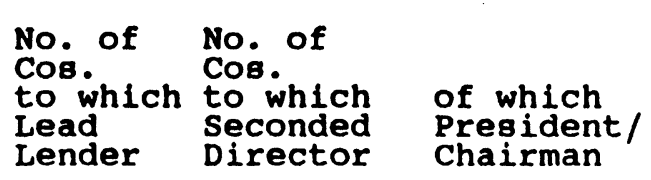

$\begin{array}{lrrr}\text { Mitsubishi } & 87 & 61 & 4 \\ \text { Sumitomo } & 78 & 42 & 4 \\ \text { Mitsui } & 78 & 31 & 2 \\ \text { Fuji } & 73 & 55 & 10 \\ \text { IBJ } & 70 & 48 & 8 \\ \text { DKB } & 61 & 58 & 11 \\ \text { Sanwa } & 52 & 34 & 3 \\ & & & \\ \text { LTCB } & 20 & 4 & 0 \\ \text { Tokai } & 17 & 13 & 1 \\ \text { Daiwa } & 9 & 16 & 1 \\ \text { Saitama } & 8 & 0 & 0 \\ \text { Kyowa } & 6 & 12 & 0 \\ \text { Taiyo-kobe } & 5 & 7 & 1 \\ \text { JCB } & 4 & 3 & 0 \\ \text { BoTokyo } & 2 & 7 & 1 \\ \text { Hok. Taku. } & 1 & 8 & 0\end{array}$

Hok. Taku.

$$
\text { (18t Section Tokyo) }
$$

$\begin{array}{ll}\text { No. of } & \text { No. of } \\ \text { Cos. } & \text { Cos. } \\ \text { to which to which } \\ \text { Lead } & \text { Seconded } \\ \text { Lender } & \text { Director }\end{array}$

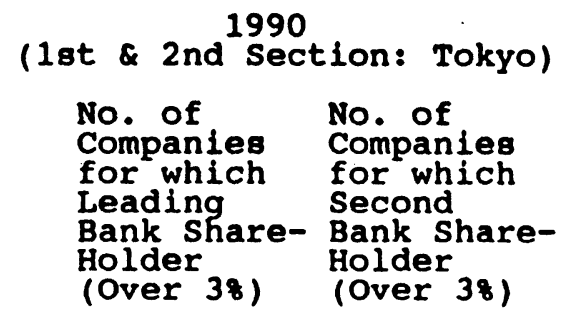

$\begin{array}{rr}83 & 129 \\ 77 & 106 \\ 48 & 89 \\ 116 & 137 \\ 85 & 106 \\ 127 & 127 \\ 102 & 132\end{array}$

Source: Keizai Chosa Rai Reiretsu no Kenkyu First section Listed Company Volumes pp. 75-91 230278 (1968); sections on Loans and personnel (1991). Kigyo Keiretsu Soran, p. 74 (1991); p. 78 (1992).

Notes: Following the conventions of keiretsu no kenkyu, the loans of all

financial institutions in the six major bank groups (and the Tokai group) have been aggregated to determine the largest lender. Companies which are seconded directors are calculated for the city banks individually

figures for 1967 are the sum of the pairs of pre-merger banks. Shareholding
numbers for Mitsui and Taiyo-Kobe are from 1989. 
Table 6

Comparison of IBJ Clients and Paired Sample (1989/90)

IBJ is Main Bank

Rest of Paired Sample

Mojor Keiretsu Benk is MB Other City Bank is MB affiliation unclear

Entire Semple

\begin{tabular}{|c|c|c|c|c|}
\hline $\begin{array}{l}\text { of } \\
\text { Firms }\end{array}$ & $\begin{array}{l}\text { Met } \\
\text { Sales } \\
\text { (M Yen) }\end{array}$ & $\begin{array}{l}\text { Outst. } \\
\text { Loans } \\
\text { (M Yen) }\end{array}$ & $\begin{array}{l}\text { Loan } \\
\text { Share } \\
\text { from } \\
\text { Group }\end{array}$ & $\begin{array}{l}\text { Loan } \\
\text { Share } \\
\text { from } \\
\text { Group } \\
\text { Bank }\end{array}$ \\
\hline
\end{tabular}

$73 \begin{array}{ll}202,670 & 63,930 \\ (60,332) & (24,431)\end{array}$

$73 \begin{array}{ll}182,120 & 73,197 \\ (52,709) & (31,085)\end{array}$

$\begin{array}{lll}54 & 222,736 & 90,496\end{array}$

$\begin{array}{rrr}13 & 35,220 & 11,824 \\ 6 & 134,853 & 50,479\end{array}$

$146 \quad 192,395 \quad 68,564$

$\begin{array}{ll} & \text { JDB } \\ & \text { Loan } \\ \text { * of } & \text { Share for } \\ \text { Firms } & \text { Firms } \\ \text { W/ JDB } & \text { W/ JDB } \\ \text { Loans } & \text { Loans }\end{array}$

Debt/
Coebt
Equity

$\begin{array}{ll}31.6 \% & 31.4 x * * \\ (2.0 \%) & (2.0 \%)\end{array}$

$\begin{array}{ll}31.8 x & 24.3 x \\ (1.9 x) & (1.7 x)\end{array}$

$33.2 x \quad 23.1 \%$

$32.5 \% \quad 32.5 \%$

$\begin{array}{ll}37.6 x & 32.5 x \\ 17.0 x\end{array}$

28

$$
\begin{aligned}
& 12.0 x \\
& (2.7 x)
\end{aligned}
$$

$67.4 x$
$(1.9 x)$

23

$11.9 \%$
$(2.9 \%)$

$70.6 \%$

$11.0 \%$

$1.3 x$
21.14

$70.6 \%$

$73.3 \%$
$64.8 \%$

$11.9 x$

$69.0 \%$

$31.7 x \quad 27.8 x$

$\begin{array}{lll} & \text { Long- } & \text { Bonds/ } \\ & \text { Term } & \text { Long- } \\ \text { Loans/ } & \text { Loans/ } & \text { Term } \\ \text { Debt } & \text { Loans } & \text { Liab. }\end{array}$

No. of which

Firms Lead Firm

wich in Group

are Has IBJ

AFFIL as MB

Sources: Nikkei data tapes, Columbia University; Keiretsu no Kenkru (1991), section on loans; Kigyo Keiretsu Soran (1990,1991), sections on Loans; Nihomo Kigyo Grupu (1991).

Note: All data except those in Number of Firm Colums are arithmetic averages of subsemple values. The standard error of the mean is in parentheses. One asterisk denotes statistically significant difference between means of IBJ semple and rest of paired sample at 10X level, two denote statistical significance of the $5 x$ level. 
Ehibit 1

The Purchasers of Coupon Debentures by Type

$1952-1955 \quad 1956-1965 \quad 1966-1975 \quad 1976-1985 \quad 1986-1990$

$\begin{array}{lccccc}\text { Government } & 45.8 \% & 14.9 \% & 6.6 \% & 3.1 \% & 1.8 \% \\ \begin{array}{l}\text { City Banks } \\ \text { Regional Banks }\end{array} & 18.2 \% & 15.7 \% & 9.8 \% & 9.5 \% & 8.9 \% \\ \begin{array}{l}\text { Other Financial } \\ \text { Institutions }\end{array} & 3.4 \% & 44.7 \% & 26.8 \% & 10.0 \% & 5.3 \% \\ \begin{array}{l}\text { Individuals } \\ \text { Int }\end{array} & 10.3 \% & 19.8 \% & 18.2 \% & 16.6 \% \\ & 0.8 \% & 14.4 \% & 37.0 \% & 59.2 \% & 67.3 \%\end{array}$

Sources: Shimura, 1980: App., 82-83, for figures before 1978, Bank of Japan Economic Statistics Annual, for subsequent years.

Note: Percentage figures are averages of yearly percentages for purchasers of coupon debenture issues. Percentages before 1978 include only coupon debentures issued by long-term credit banks. The category of individuals includes non-financial companies. 
Exhibit 2: Outstanding

Financial Debentures by Type

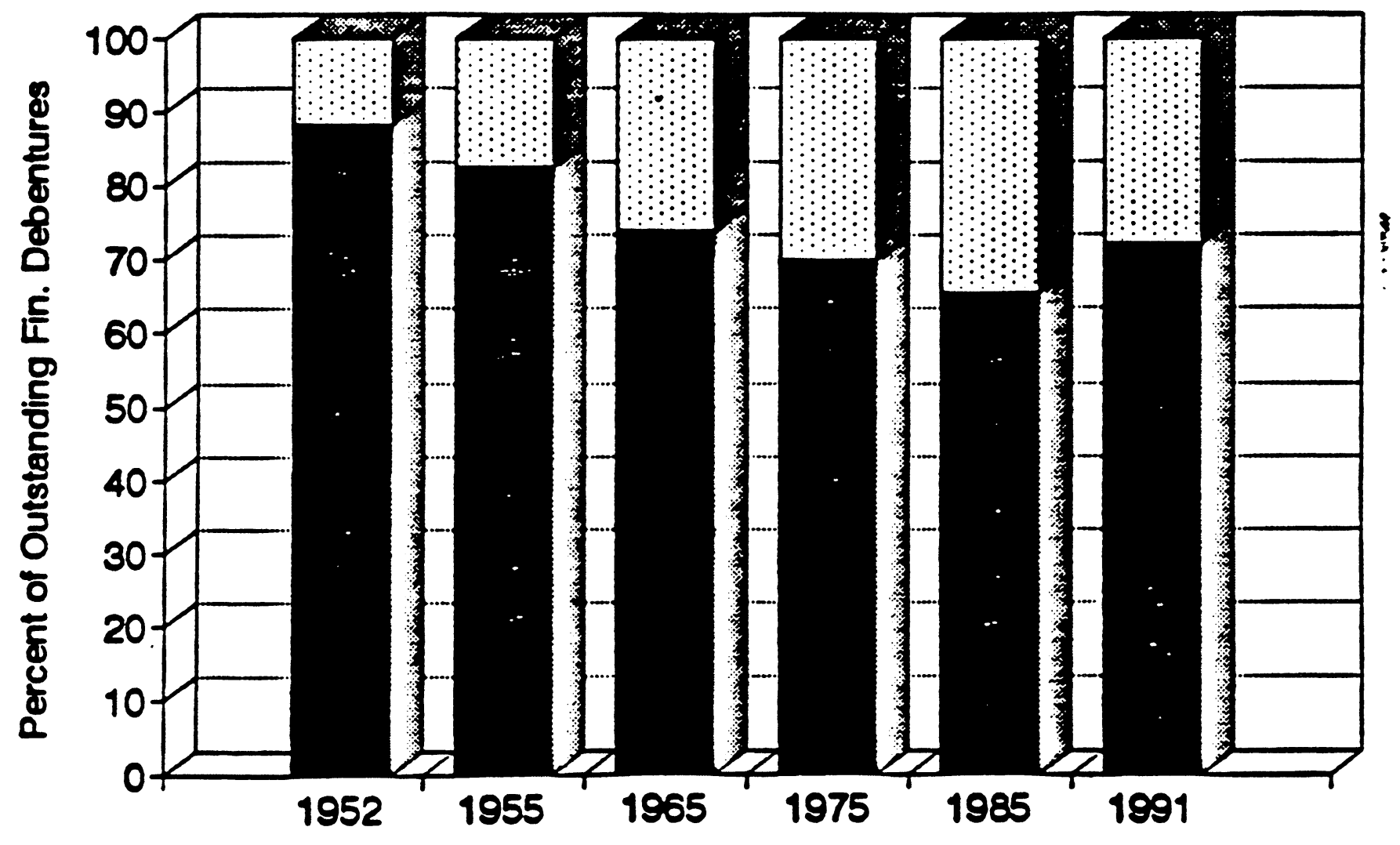

Coupon Debentures Discount Bonds

Source: Bank of Japan Economic Statistics Anoual, various yeara. 


\section{Exhibit 3: The Distribution Channels for Discount Bonds}

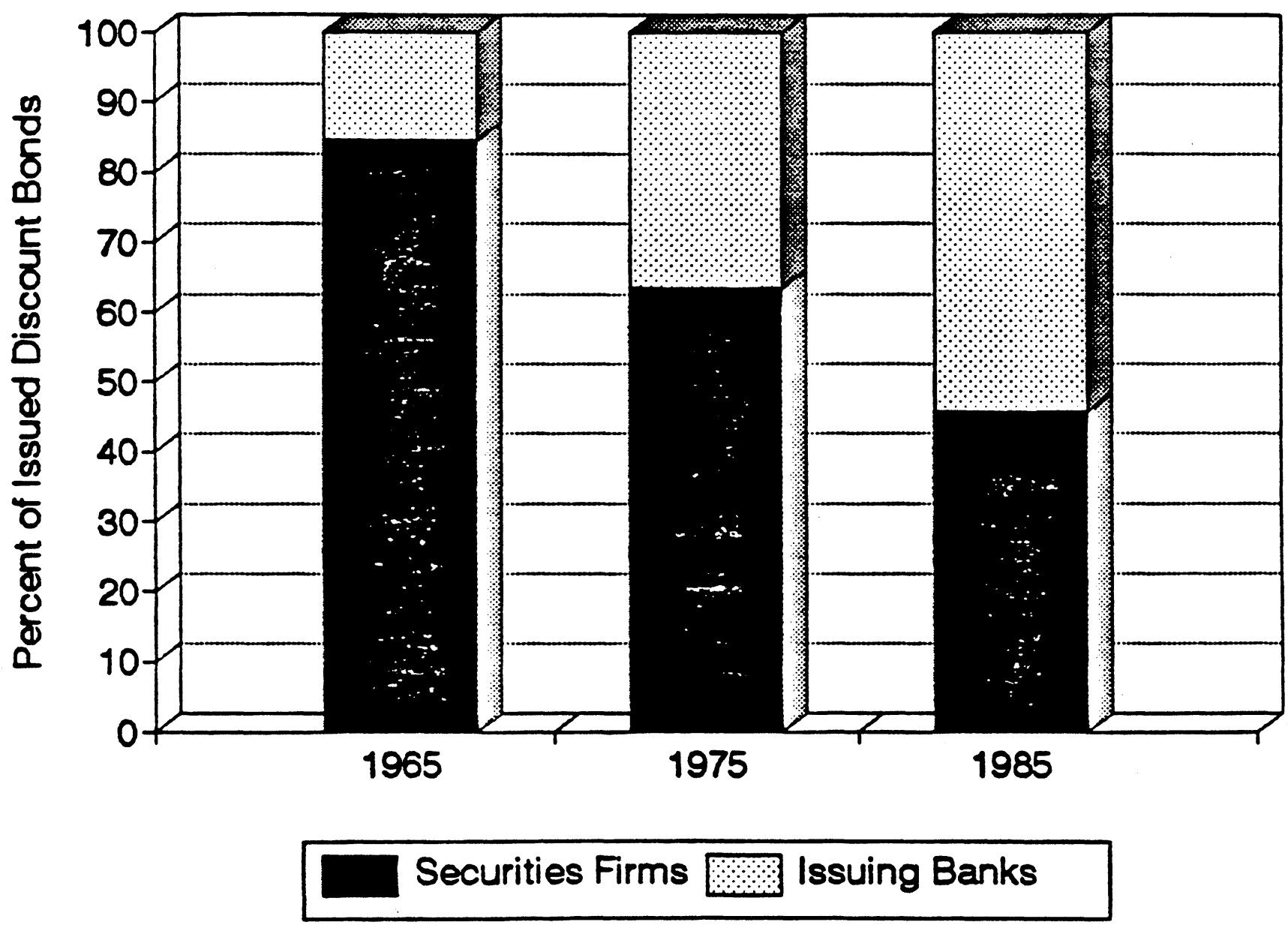

Source: Kinus Seido Chosakai, 1987: statistical appendix, 70.

Note: Includes only bonds issued by the long-term credit banks. 
Exhibit 4: Financial Debentures and the Japanese Bond Market

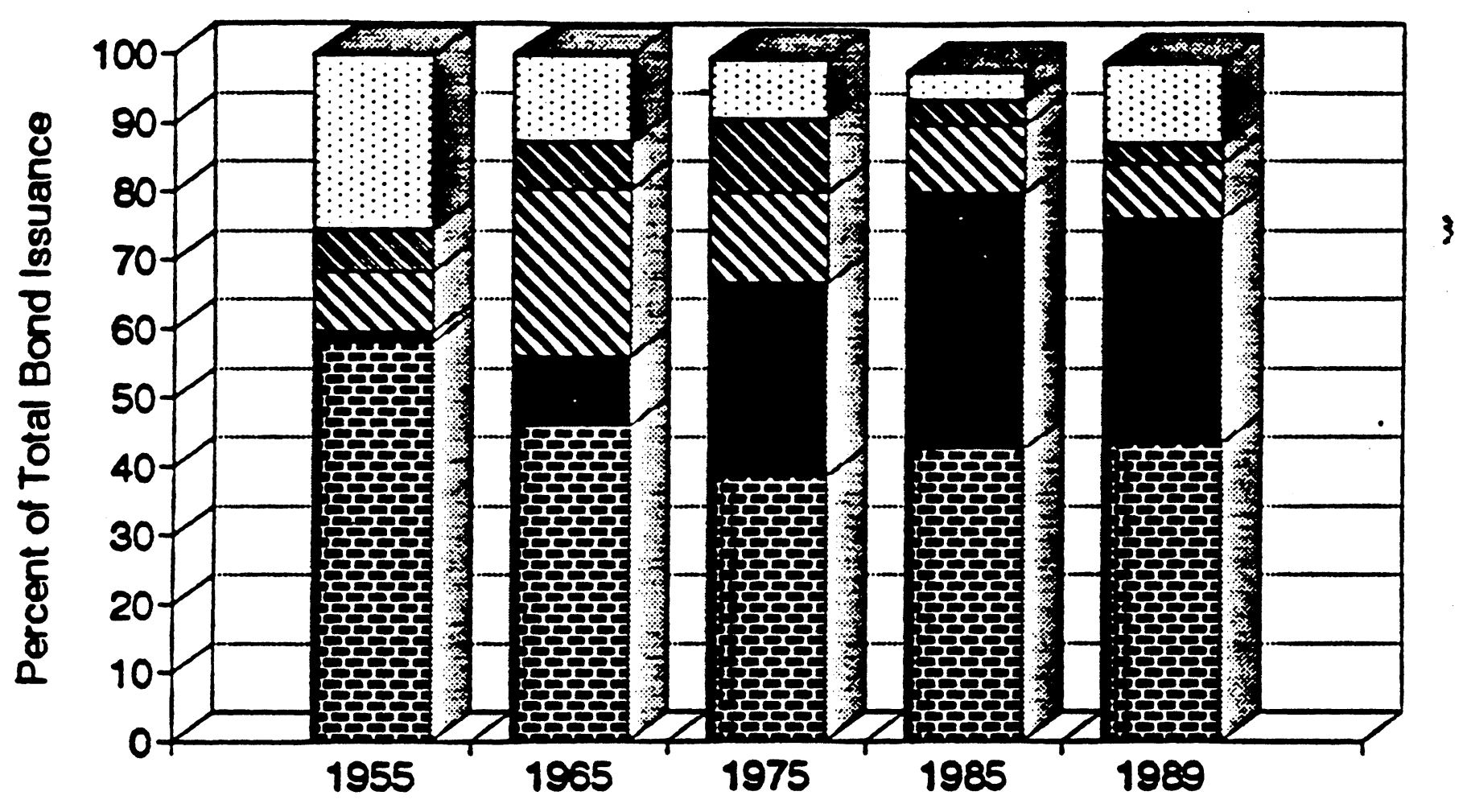

Fin Fov. Bonds Nentures P. Corp. Bonds NIV Municipal Bonds Corporate Bonds

Sources: Shimura, 1980: App, 38-47; Koshasai Yoran, 1990. 


\section{Exhibit 5: The Distribution of Loans from Major Bank Groups (1965)}

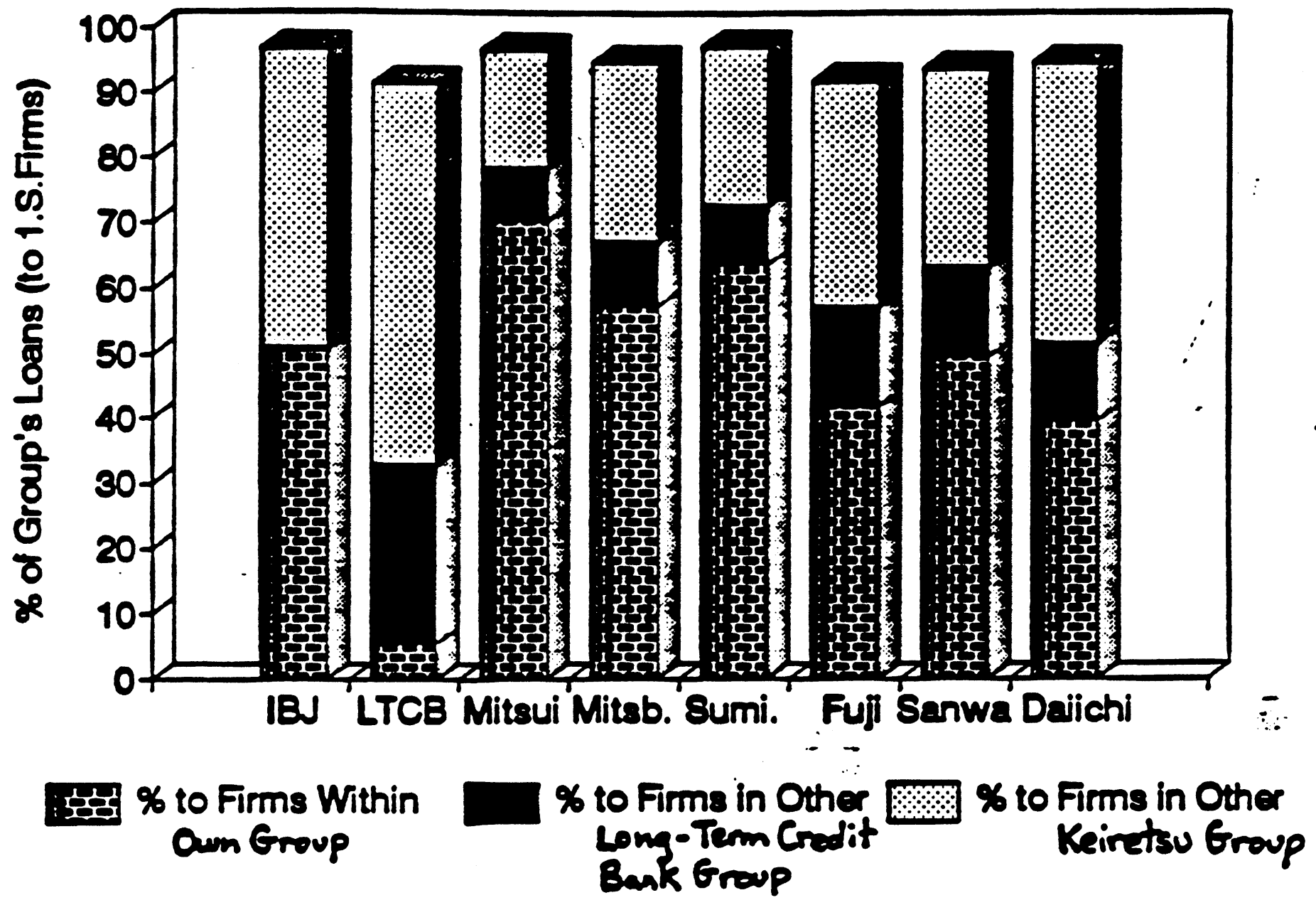

Sources: Cocutrueted from dint in Shimurn, 1978: 161, the ecurce

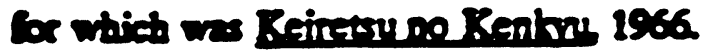

Notes: IBJ and LTCB constitute the onty leading institutions of their "groups" A firm's group is ideotified as that froup whose finnocial institutions in ageregate provide the most bans to the firm. 
Exhibit 6: The Position of 2nd Largest

Lender: L-T Credit Banks and Others

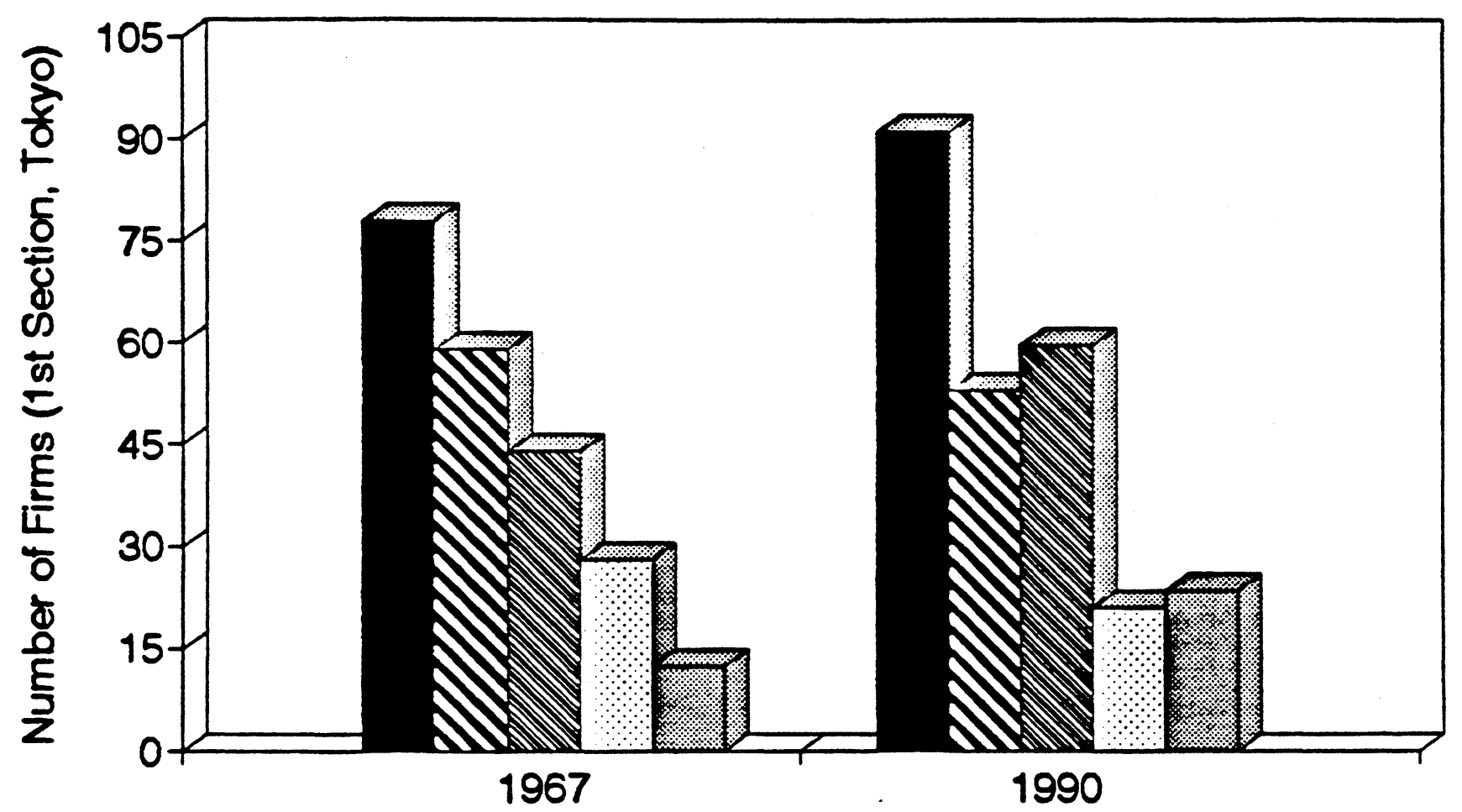

\begin{tabular}{ll}
\hline IBJ & MI LTCB \\
NCB & Other City Banks (Avg.)
\end{tabular}

Sources: Keiretsu no Kentru, 1968, 1991.

Note: The loans of group city and trust banks, insurance and trading companies are aggregated when calculating the position of the "group bank" 


\section{Exhibit 7: The Collateral of IBJ Loans compared to that of All Banks}

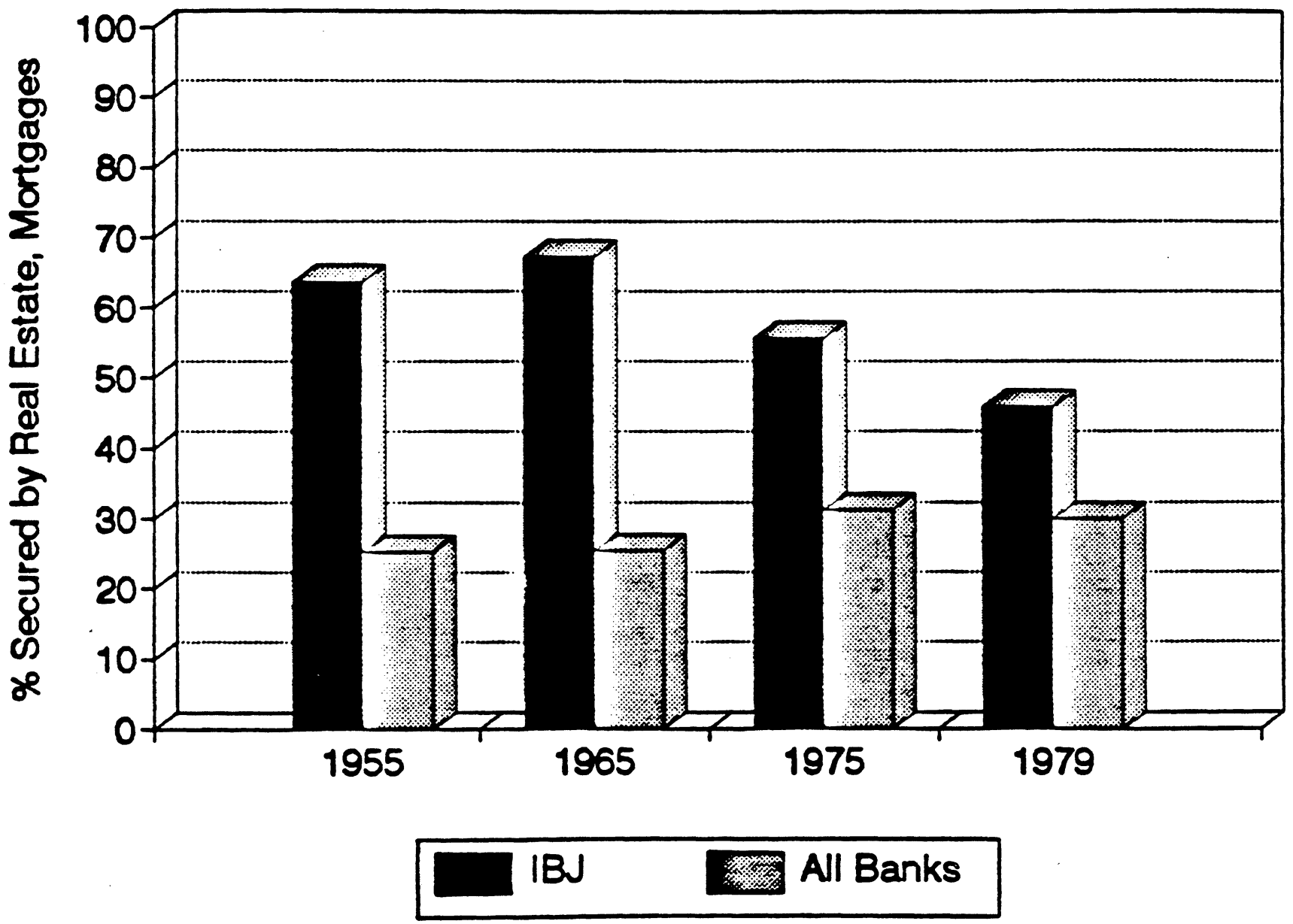

Sources: Bank of Japan Ecopomic Statistics Annual, various years; IBJ History. 


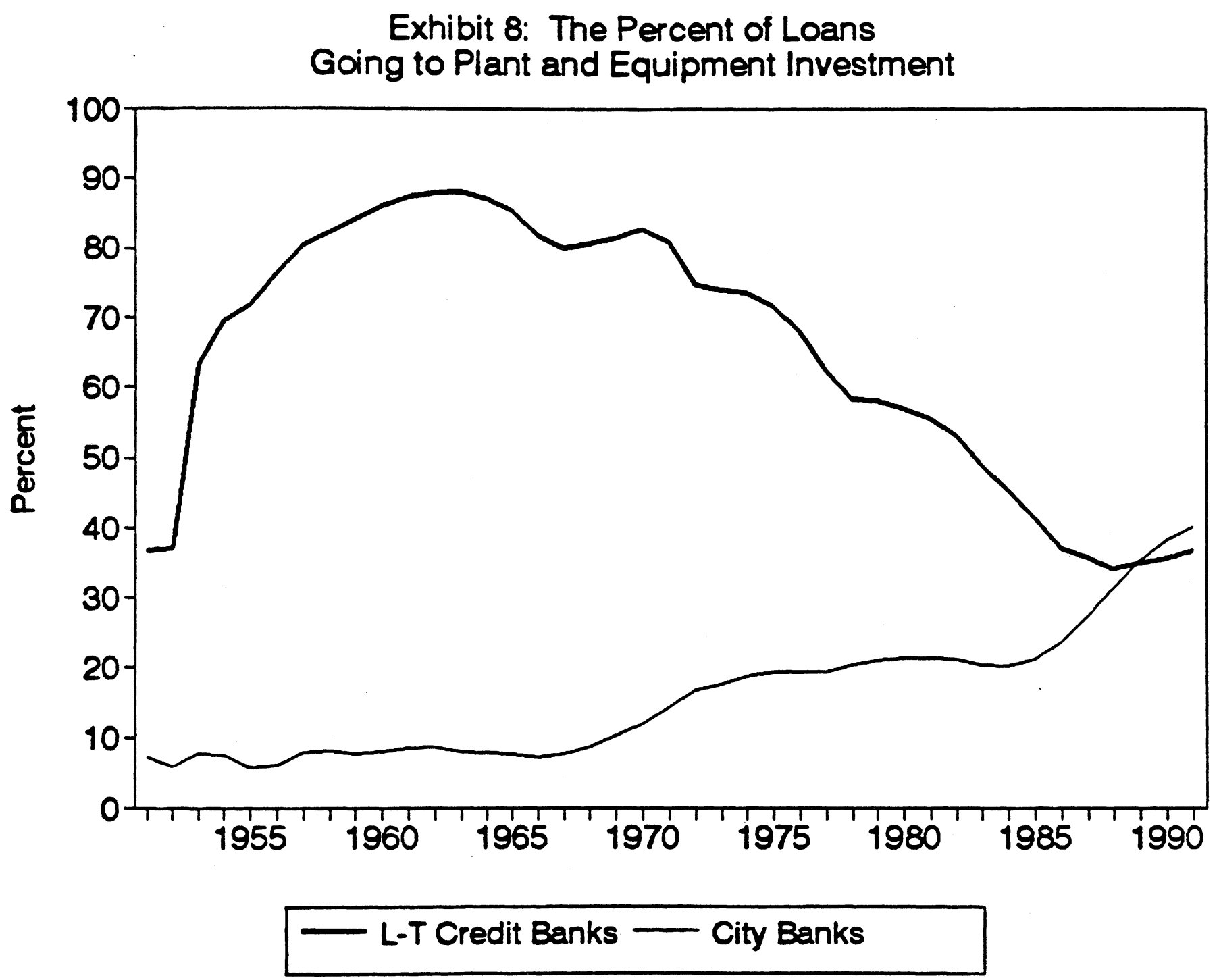

Source: Bank of Japan Economic Statistics Annual, various years. 


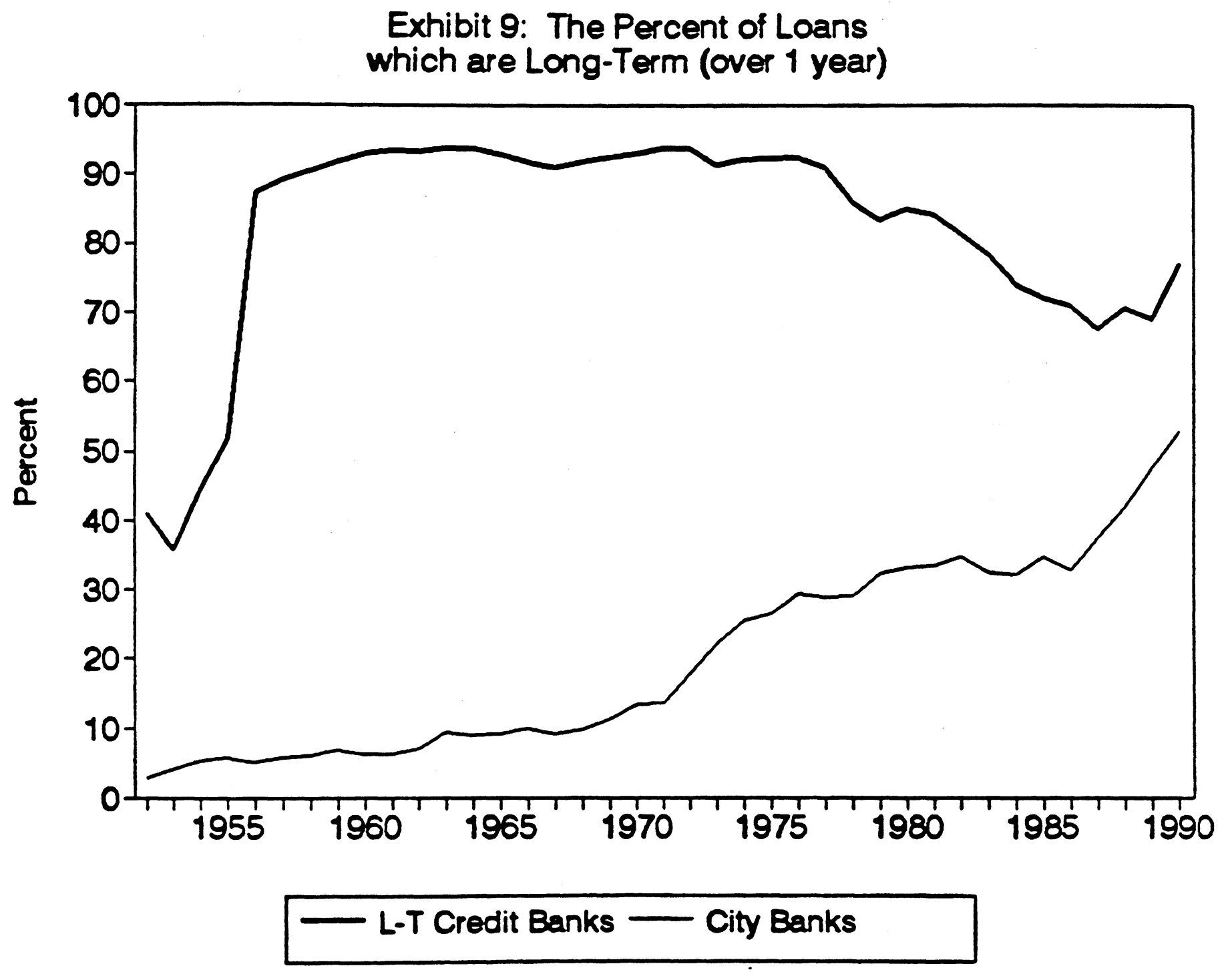

Source: Bank of Japan Economic Statistics Annual, various years. 
Exhibit 10

\section{THE IBJ GROUP}

Fisheries

Construction

$\underline{\text { Textiles }}$

Paper and Pulp

$\underline{\text { Oil }}$

Iron and Steel

Specialty Steel

Non-ferrous Metals

Chemicals and Glass

Industrial Machinery

Shipbuilding

Automobiles

Household Electronics

Precision Machinery

Banks/Securities Companies

Restaurants/Leisure

Railways

Shipping

Airlines
Taiyo Fishery, Nippon Suisan

Aoki Construction, Toyoko

Nitto Boseki, Kuraray

Daishowa Paper, Tomoku, Superbag

Cosmo Oil

Nippon Steel, Godo Steel, Taiheiyo Metals,

Daido Steel, Nippon Yakin Kogyo

Nippon Mining, Dowa Mining

Tosoh, Nippon Soda, Chisso Corporation, Nippon Steel Chemical, Rasa Industries, Nissan Chemical Industry, Hodogaya Chemical, Central Glass

Zexel, Ikegai, Riken

Nitchitsu

Nissan Motors, Nissan Diesel Motor, Fuji Heavy Industry

SMK

Aichi Tokei Denki, Riken Keiki, Copal

Tokyo Tomin Bank, Japan Securities Finance, New Japan Securities. Wako Securities, Toyo Securities

Royal, Tokyo Disneyland, Yomiuri Land

Keisei Electric Railway, Nishi Nippon Railroad

Navix (formerly Japan Line), Shinwa Kaiun

Japan Airlines

Source: Dodwell \& Co., Industrial Groupings in Japan, Eighth Edition, 1988/1989, p. 134; Osono, p.52-53. Some of these companies are also considered members of other groups. 